\title{
Review of Stock Markets' Reaction to New Events: Evidence from Brexit
}

\author{
Isaac Quaye ${ }^{1 *}$, Yinping Mu1 , Braimah Abudu' ${ }^{1}$, Ramous Agyare ${ }^{2}$ \\ ${ }^{1}$ School of Management and Economics, University of Electronic Science and Technology of China, Chengdu, China \\ ${ }^{2}$ School of Business, University of Shanghai for Science and Technology, Shanghai, China \\ Email: *mrquaye2000@yahoo.com
}

How to cite this paper: Quaye, I., Mu, Y., Abudu, B., \& Agyare, R. (2016). Review of Stock Markets' Reaction to New Events: Evidence from Brexit. Journal of Financial Risk Management, 5, 281-314. http://dx.doi.org/10.4236/jfrm.2016.54025

Received: November 11, 2016 Accepted: December 27, 2016

Published: December 30, 2016

Copyright (c) 2016 by authors and Scientific Research Publishing Inc. This work is licensed under the Creative Commons Attribution International License (CC BY 4.0).

http://creativecommons.org/licenses/by/4.0/ (c) (i) Open Access

\begin{abstract}
Several studies have evolved to deal with the determinants of stock market volatility. However, there exists a gap in literature with regards to the interrelation among the broad categories of factors that trigger stock market reaction namely company fundaments, technical factors and market sentiments. This paper provides a holistic and comprehensive theoretical review of drivers of stock markets' reaction as well as designs an interrelated conceptual framework of the factors that influence investors' decision making to fill the gap in literature. Brexit is presented as a case study to illustrate how investors and stock markets are affected by new events or information. This study will reveal some of the global staggering effects of Brexit at the end of trading on June 24, 2016 in areas such as currencies, stock markets, banks, commodities, bonds, automakers and homebuilders as well as hedge fund. Barely 24 hours after the results of Brexit were declared; global stock markets lost about \$2 trillion in value. The British pound plunged to almost $\$ 1.33$, its lowest level in over 30 years against the US dollar and gold proved to be one of the few safe havens for investors on that day. In order for investors to insulate themselves against loses from Black Swans events, the conclusion of this study recommends some protective mechanisms for investors which include avoidance of overexposure and stockpiling of cash.
\end{abstract}

\section{Keywords}

Stock Market, Information, Brexit, Volatility, Referendum

\section{Introduction}

Investors are wealth maximization oriented individuals who are always itching for higher returns on their investments in firms listed on stock exchanges. According to (Njanike et al., 2009), a stock exchange is essentially a market place for stocks and 
bonds; with stockbrokers earning a small commission on each transaction that they make. The performance of a stock market, according to (Ibrahim \& Aziz, 2003), can be affected by "influence". Influence can be defined as a power to affect persons or events based on prestige thus causing something without any direct or apparent effort (Maria, 2013). (Seyhun, 1998) asserts that influence is basically causative factor that exerts pressure on a person or events to drive them to perform in a certain way. A factor is anything that contributes casually to a result and drives a certain performance in an event (Njanike et al., 2009). The concept of influencing is as old as warfare itself, and was a significant aspect of war for theorists such as Sun Tzu and Carl von Clausewitz (Maria, 2013). However, with the end of the Cold War and the explosion of information technologies, the concept of influencing became much more focused on information. Consequently, the high returns expectation will be dependent on both good internal and external information; whereas bad information or event may result in low returns. Therefore, investors expect stock prices to react to some new information or events (Schweitzer, 1989). The starling nature of stock markets' reaction to new information is highlighted by (Fama et al., 1969; Woolridge \& Snow, 1990; Rigobon \& Sack, 2003; Vega, 2006; Shapira et al., 2014). This assertion is supported by (Swedroe, 2013) as the report reveals the existence of a significant body of literature measuring the speed and the efficiency of the market adjustment to new information. According to (Swedroe, 2013), the major adjustment to the information released (and the window for trading profits) lasts about 40 seconds in the US fixed income markets whereas it takes 75 - 90 seconds for UK equities markets to adjust to new information. (Smales, 2013) throws more light on the stupendous complexity of the stock market reaction to new data. The study investigated into how the Australian bond market reacts to information. The study covered the period spanning the great financial crisis, 2005-2010. (Smales, 2013) concluded that adjustment to new information on the Australian bond market occurs quickly with the significant part of the reaction complete within 30 seconds. As stock markets react to new information, the challenge for investors is the fact that they are usually uncertain about the timing, magnitude and direction of the reaction (Schweitzer, 1989). Many studies have been conducted on several announcements of new information or events and their impact on stock prices as well as the performance of stock markets as a whole. According to (Agrawal et al., 2010), announcements or new information about enterprise performance, dividends, stock prices of other countries, gross domestic product, exchange rates, interest rates, current account, money supply and employment have an impact on daily stock prices (Kurihara, 2006). Other events or announcements that have the tendency of triggering volatility of the stock market include rail accidents (Walker et al., 2006), product and market diversification (Jones \& Danbolt, 2005), mergers and acquisitions (Liang, 2013), punitive damages (Lott \& Karpoff, 1998), new product introduction (Lee et al., 2015), stock split (Subaih, 2013), natural disasters (Maierhofer, 2011), awards (Bu \& Tian, 2012), corporate press releases (Neuhierl et al., 2013), media and celebrity endorsements (Ding et al., 2011; Doukas, 2013) and supply chain disruptions (Hendricks \& Singhal, 2008). The 
impact of most of these announcements or events on stock performance is usually firm-specific, industry-specific or geographic-specific. Events which have the propensity of triggering global stock market reaction rarely occur. One of such events was the collapse of the Lehman Brothers in 2008 which sent a wave of panic around world financial markets (McKibbin \& Stoeckel, 2009). The repercussion of the collapse of the Lehman Brothers was worldwide recession which was the first since Second World War (Dullien et al., 2010). (Norgren, 2010) reveals that several factors combined to make this one of the most severe crisis since the Great Depression of the 1930s, which included macroeconomics problems, failures in financial markets as well as short comings in the implementation of policy. There are many literature that have emerged to deal with determinants of stock market volatility or reaction. However, most of the literature primarily focus on macroeconomic variables only, technical factors only and market sentiments only. Therefore, this paper provides a holistic and comprehensive theoretical review of drivers of stock markets' reaction as well as designs an interrelated conceptual framework of the factors that influence investors' decision making. Moreover, this study presents Brexit as a case study to illustrate how investors and stock markets across the globe are affected by new events or information. The UK in a referendum voted to exit from the EU on June 23,2016 . The event popularly christened as Brexit sent immediate shock waves across the world just a day after. Consequently, the Brexit plunged the global stock markets into financial turmoil. Thus, this paper will reveal some of the global staggering effects of the Brexit's results at the end of trading on June 24, 2016 in areas such as currencies, stock markets, banks, commodities, bonds, automakers and homebuilders as well as hedge fund. The remainder of this paper is structured as follows: Sections 2 and 3 present stock markets' reaction determinants and road to Brexit. Global Financial reaction to Brexit is captured in section 4 whiles sections 5 and 6 cover conclusion and future research respectively.

\section{Stock Markets' Reaction Determinants}

The concept of determinants of share price was initiated by (Collins, 1957) for the US market and since then a significant body of theoretical and empirical literature has evolved that considers the determinants of market price of shares as well as the volatility of the stock market as a whole (Sharif et al., 2015). The importance of stock markets' contribution to an economy cannot be relegated to the background as the stock market helps in accumulating domestic resources and directing them to productive investment (Atiq et al., 2010; Aurangzeb, 2012; Vincent \& Bamiro, 2013). The significant roles of stock market to economic development is reiterated by (Shrestha \& Biggyan, 2014) as the study suggests that growth in stock market index is normally considered as a good sign since it implies that investors are confident about the future prospect of the economy. Investors as well as the stock market will react to new information or event thereby resulting in fluctuations in stock prices and stock market indices. According to (Vincent \& Bamiro, 2013), stock prices reflect all available information and the quicker they are in absorbing accurately new information, the more efficient is the stock market 
in allocating resources. (Vincent \& Bamiro, 2013) also opine that fluctuations of stock prices and stock indices results into problem of uncertainties which have to do with the accurate prediction of the short and long-term future state of the stock prices. However, the magnitude of financial players' response to new information or event is likely to depend on the extent of the information asymmetry between the investors and the handlers of the new events or information, some of them which can never be anticipated to occur especially with natural disasters (Khan, 2009). Information asymmetry occurs when one category of people enjoy better or more-timely information than other category in a system (Copeland \& Weston, 2005). There are many factors that have the tendency of affecting stock prices and the stock market in general (Shrestha \& Biggyan, 2014). Studies by (Atiq et al., 2010; Al-Tamimia et al., 2011) categorized the factors that affect stock market to include company fundamentals, technical or external factors and market sentiments (behavior).

\subsection{Company Fundamentals}

A study by (Al-Tamimia et al., 2011) highlight some of the fundamental factors of a company that might influence stock prices to include performance of the company, a change in board of directors, appointment of new management, and the creation of new assets, dividends, earnings, etc. A book titled "Corporate Finance: A Focused Approach" by (Ehrhardt \& Brigham, 2014) states that "shareholders care about all dividends, both current and those expected in future". The authors also argue that growth in earnings per share (EPS) is a catalyst for growth in dividend. Moreover, (Zacks, 1979) postulates that earnings prospect of a company is a major consideration factor for many investors when making their investment decisions. Thus, dividend per share (DPS) and earnings per share (EPS) are considered as the most important fundamental factors affecting stock prices (Atiq et al., 2010; Sharif et al., 2015). (Hartono, 2004) examines the effect of a sequence of positive and negative dividend and earning information on stock prices. Data for this study were collected from Center for Research in Security Prices (CRSP) tapes in the US from 1979 to 1993 . The study concludes that the positive recent earning information has significant relation with stock prices when it follows negative dividend information, and the negative recent earning information has significant relation with stock prices when it follows positive dividend information. On the contrary, the recent positive dividend information has significant relation with stock prices when it follows negative earning information while the recent negative dividend information does not have significant relation with stock prices when it follows positive earning. This study shows short-term reaction of stock prices to the earnings and dividend information and does not reflect long-run dynamic relation. (Chang et al., 2008) conducted a research study on the Taiwan Stock exchange (TSEC) in order to know the relationship between EPS, DPS, and the stock prices. They selected 75 firms, collected data for these firms from 1997 to 2006, and used panel co-integration methods for their analysis. Their study revealed that EPS has a positive effect on the stock price while DPS does not affect stock prices in the long run. (Sharif et al., 2015) 
conducted a study into factors affecting share prices on the Bahrain Stock Exchange. The analysis of the study was based on a panel data set of 41 companies listed in the Bahrain stock exchange for the period 2006-2010. Eight firm specific variables namely return on equity (ROE), book value of share (BVS), earnings per share (EPS), dividend per share (DPS), dividend yield (DY), price earnings (PE), debt to total assets (DA) and controlled by firm size (LogMCAP), were studied to infer their impact on market price of shares (MPS) in the respective market. The findings of the study include dividend per share (DPS) was found to be significant determinant of stock prices in the Bahrain market. However, the study revealed a negative relation between earnings per share (EPS) and market price per share. This contradicts the findings obtained by (Somoye et al., 2009; Khan et al., 2011). Consequently, EPS is not considered as a significant determinant of stock price by investors in Bahrain as they are aware that EPS can increase not only because of the increase in profits but also due to stock repurchases (Sharif et al., 2015).

\subsection{Technical Factors}

The investing community will be relieved if only stock prices are set by fundamental factors. However, stock prices and the movement of the entire financial market are also affected by external or technical factors. Technical factors are the mix of external conditions that alter the supply of and demand for a company's stock (Atiq et al., 2010). These factors might include macroeconomic variables such as inflation, gross domestic product (GDP), foreign direct investment (FDI), money supply, consumer price index (CPI), exchange rate, interest rate, industrial output, and oil price. According to (Aurangzeb, 2012), the growth of a country is directly related to its economy which consists of the various macroeconomic variables. (Ibrahim \& Aziz, 2003) explored the relationship between four macroeconomic variables and Kuala Lampur Composite Index (KLCI) by using the monthly data of their variables which were real output, inflation rate, money supply and exchange rate from 1977 to 1998 and their model suggested that there is short term relationship as well as long term relationship exist between the macroeconomic variables and the KLCI. (Liu \& Shrestha, 2008) conducted investigation into the long run relationship between Chinese stock market and a set of macroeconomic variables which includes industrial production, exchange rate, inflation, money supply and interest rate from 1992 to 2001. The conclusion of this study indicates that industrial production and money supply have the positive relationship with Chinese stock indices while inflation, interest rate and exchange rate have the negative impact on stock prices. In the nutshell, (Wu \& Lee, 2015) highlight that macroeconomic variables act as indicators of stock market and may affect future consumption and investment opportunities. Thus, they play significant role in determining stock prices.

Apart from the aforementioned macroeconomic variables, other technical factors that may affect stock prices include market conditions, competition, political events and governmental policies, terrorism, uncontrolled natural or environmental circumstances directly affecting the production of the company, strikes, wars, fraud, etc. (Adam 
\& Tweneboah, 2008; Al-Tamimia et al., 2011). According to (Rudd, 2009), global equity markets lost approximately US $\$ 32$ trillion in value since their peak during the 2009 global financial crisis as a result of the collapse of Lehman Brothers in 2008. (Beaulieu et al., 2006) investigated the short run impact of the political uncertainty associated with the 1995 Quebec referendum on the stock returns. It was established that the uncertainty surrounding the referendum outcome had short run impact on stock returns of Quebec firm, implying that the stock market was directly influenced by the political risk and uncertainty. In 2010, BP oil spill resulted in estimated 4.9 million barrels of oil released into the Gulf of Mexico, contaminating the waters and surrounding shorelines (Brennan, 2013). As a result of the spill, stock prices of BP plummeted (Tse, 2010). (COSO, 2010) examined financial statement fraud allegations investigated by the US Securities and Exchange Commission over a ten-year period and found that news of an alleged fraud resulted in an average $16.7 \%$ abnormal stock price decline in the two days surrounding the announcement. (Luo, 2012) investigated the impact of the Japanese earthquake in 2011 on six most representative stock markets all over the world and concluded that all the six stock markets reacted to the earthquake negatively. (Johnston \& Nedelescu, 2005) cite a study by (Chen \& Siems, 2004) attempted to statistically test the significance of the September 11 terror attacks on USA on global capital markets by measuring the deviation of index returns from their average. The study concluded that the event had a widespread negative impact on all the markets. This is depicted in Table 1 which shows the abnormal returns in the aftermath of the September 11 terrorist attacks for banking/financial sector indices from 14 global capital markets.

Table 1. Average abnormal returns on global capital markets following the September 11 terrorist attacks.

\begin{tabular}{ccccc}
\hline $\begin{array}{c}\text { Global Stock Markets' } \\
\text { Banking/Financial Sectors }\end{array}$ & $\begin{array}{c}\text { Event-day AR } \\
(\%)\end{array}$ & $\begin{array}{c}\text { 6-day CAR } \\
(\%)\end{array}$ & $\begin{array}{c}\text { 11-day CAR } \\
\text { (\%) }\end{array}$ & $\begin{array}{c}\text { Days to } \\
\text { rebound }^{2}\end{array}$ \\
\hline NYSE & -4.79 & -6.69 & -0.45 & 13 \\
London & -10.09 & -8.64 & -14.14 & 22 \\
Frankfurt & -10.06 & -14.54 & -15.79 & 42 \\
Europe-Bloomberg & -8.54 & -11.50 & -14.82 & 40 \\
Helsinki & -6.17 & -6.43 & -11.35 & 31 \\
Norway & -5.79 & -14.18 & -25.55 & 107 \\
Tokyo & -6.50 & -1.70 & -12.18 & 6 \\
Hong Kong & -7.87 & -11.02 & -14.34 & 30 \\
Korea & -13.33 & -13.78 & -19.84 & 28 \\
Jakarta & -2.83 & -3.73 & -6.23 & 86 \\
Kuala Lampur & -5.20 & -13.36 & -18.68 & 65 \\
Australia & -3.98 & -9.46 & -11.07 & 26 \\
New Zealand & -3.67 & -11.39 & -14.93 & 33 \\
Johannesburg & -5.27 & -14.43 & -11.00 & 162 \\
\hline
\end{tabular}

${ }^{1}$ CAR denotes cumulative average abnormal returns; ${ }^{2}$ denotes Number of trading days for the market to return to pre-attack level; Source: (Chen \& Siems, 2004). 


\subsection{Market Sentiments}

Sentiment describes a group of people's opinions, emotions or views, and market sentiment sums such expectations for the market as a whole (Thorp, 2004). According to (Chang et al., 2004) market sentiment is measured by an approach known as investor sentiment. Market sentiment which is often subjective, biased and obstinate, is being explored by the relatively new field of behavioral finance. Behavioral finance means the study of investor's behavior and its effects on stock prices while investing in stock market (Haritha \& Uchil, 2016). The behavioral finance opposes the Efficient Market Hypothesis (EMH) which indicates that prices of securities fully reflect all publicly available information (Allen et al., 2015). (Malkiel, 2003) and other economists challenged the EMH, to explain diverging market sentiment, including how psychological and behavioral elements impact stock prices. Behavioral finance starts with the assumption that markets are apparently not efficient much of the time, and this inefficiency can be explained by psychology and other social sciences (Haritha \& Uchil, 2016). (Wang et al., 2009) cited by (Rehman, 2013) is of the opinion that human sentiments are better indicators in the determination of final security prices than any economic variables. Many studies have been conducted and found some measures of investors' sentiment predicting stock returns (Lee et al., 1991; Neal \& Wheatley, 1998; Glushkov, 2006; Baker \& Wurgler, 2006; Huiwen \& Sun, 2012; Ling et al., 2014; Zheng, 2015; Krishnan \& Satish, 2016). (Haritha \& Uchil, 2016) developed a conceptual framework to illustrate how market sentiments leads to investors' sentiments and the behavioral pitfalls affecting financial decision making. The framework which is depicted in Figure 1 was developed based on extensive literature review in the field of behavioral finance by the authors.

\subsubsection{Herd Behavior}

(Chang et al., 2000) discuss herding behavior as a method by which market participants

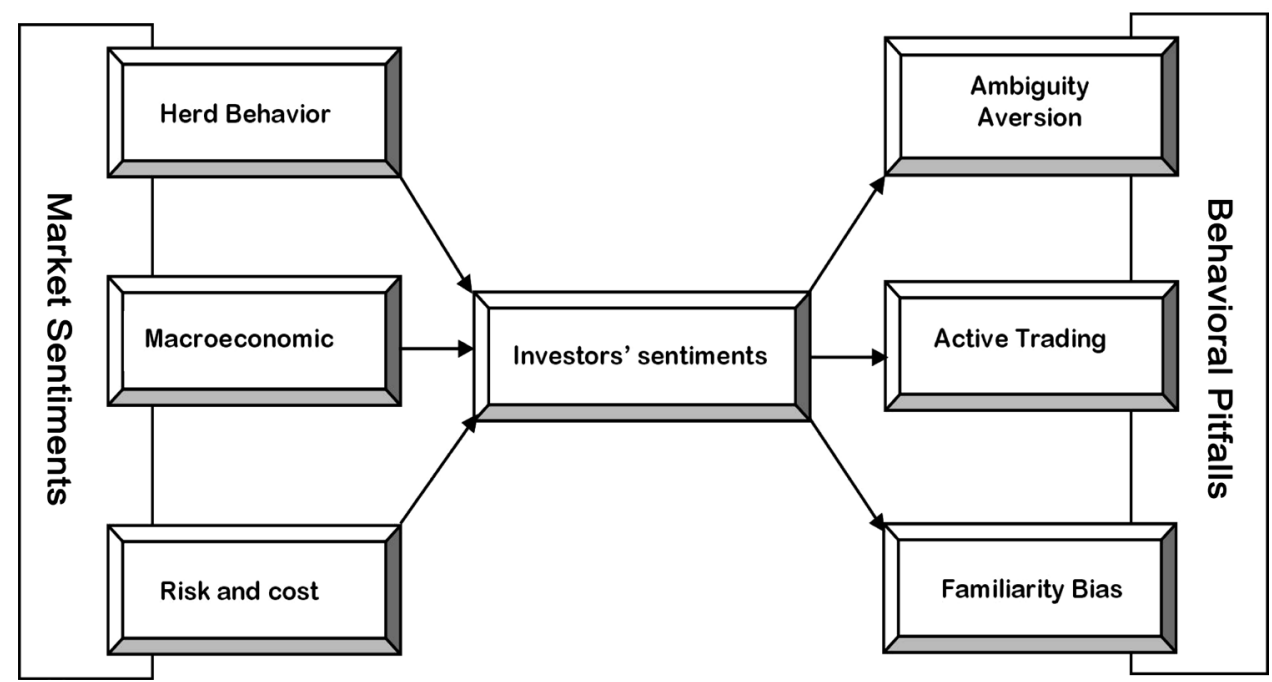

Source: (Haritha \& Uchil, 2016)

Figure 1. Conceptual framework depicting the relationship between investors' sentiments and pitfalls. 
base their investment decisions on collective arrangements alone, defeating their own opinions. (Hirshliefer, 2001) is of the opinion that the existence of herding is based on the tendency of investors to follow the same information sources, interpreting the signals carried to the market in a regular way and, therefore, enhancing similar financial decisions. There are two reasons that account for herd behavior. Firstly, the powerful force of conformity to social pressure. The acceptance of people by a group portrays a sense of belongingness. This group or societal acceptance is an essential need of human beings as illustrated by Abraham Maslow's hierarchy of needs in Figure 2. Needs associated with love and belonging are third level of the pyramid. According to Abraham Maslow, these needs are met through satisfactory relationships with family members, friends, peers, classmates, teachers, and other people with whom individuals interact (Martin \& Joomis, 2007). Therefore, individuals are fascinated to be accepted by others instead of being stigmatized as an outcast. Secondly, the common rationale that it is unlikely that such a large group could be wrong. Some people with little experience may still follow a group even if they are fully convinced that particular action is irrational. This is because they have the belief that the group may know something that they are unaware of. Several studies have focused on the extent of distortion impact caused by herd behavior on the stock market (Eichengreen \& Mody, 1998; Zaharyeva, 2009; Blasco et al., 2012; Shalom-gilo, 2013; Angela-Maria et al., 2015).

\subsubsection{Macroeconomics}

It has already been espoused by many studies how macroeconomic variables like inflation, exchange rate, money supply, unemployment rate, etc. cause price fluctuations on the stock market in general. However, do macroeconomic variables influence the individual behavior of investors in their investment decisions as being studied by behavior-

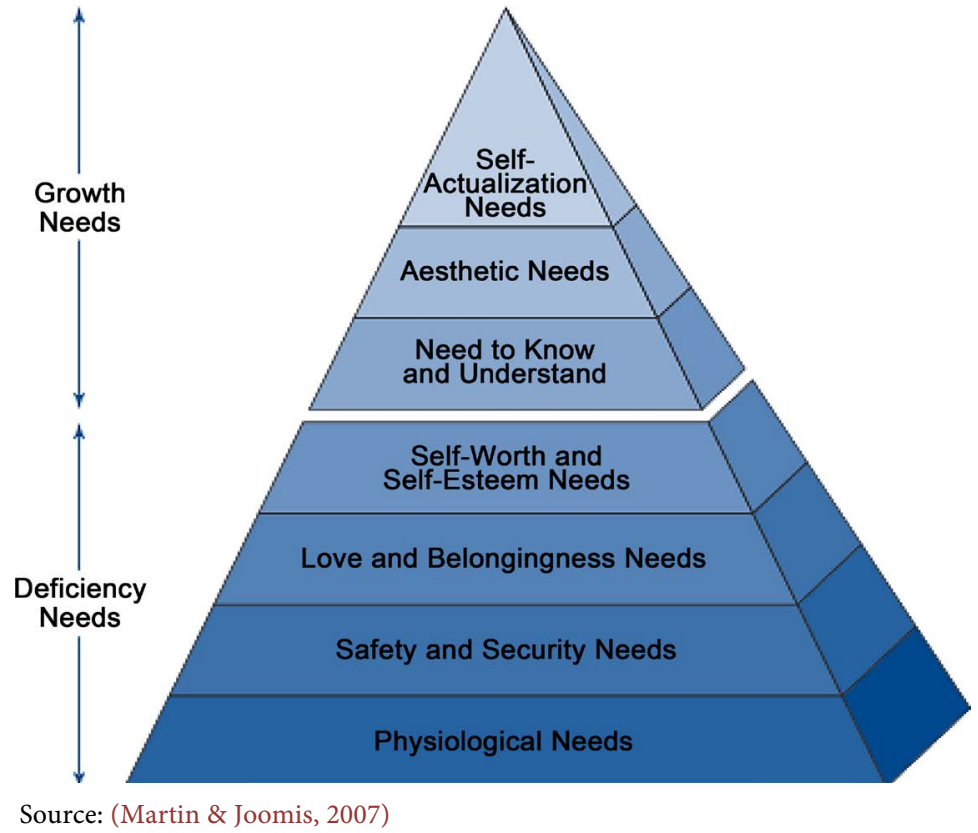

Figure 2. Maslow's hierarchy of needs. 
al finance? (Merikas et al., 2011) tested the tenets of the behavioral finance theory on the factors that influence investment choices under conditions of uncertainty on the Athens Stock Exchange (ASE). Participants were asked to evaluate the importance of 26 variables including current economic indicators, identified from the literature and personal interviews as potentially influencing stock investment decisions. 32.7\% representing 49 respondents out of 150 full responses received stated that their investment's decisions are influenced by current economic indicators. In a study carried out in Ghana on the attitude of investors, the main factors which influence investors' attitude are interest rate, unemployment rate and strength of an economy (Bennet et al., 2012). In India, investors' behavior are influenced by macroeconomic factors like rate of inflation, interest rate and strength of Indian economy (Haritha \& Uchil, 2016).

\subsubsection{Risk and Cost}

People make investment decisions based on the returns expected to be accrued to them. However, investors' expectations are sometimes not materialized as they may receive returns less than expected or the actual amount realized may be less than the initial investment. This unrealized expectation constitutes what is referred to in financial parlance as investment risk (Maranjian, 2013). (Baker et al., 1977) argue that investors behave rationally, taking into account the investment's risk/return tradeoff. There tend to be positive correlation between risks and returns in actuality, however people often perceive that the opposite relationship exists (Fischhoff et al., 1978; Akami \& Slovic, 1994; Ganzach, 2000; Hung et al., 2010). The portfolio theory of (Markowitz, 1952) cited by (Rezagholizadeh et al., 2013) posit that investors attempt to maximize the expected return of their investment portfolio for a given amount of portfolio risk, or to minimize risk for a given level of expected return, which means that an investor who wants higher expected returns must accept more risk. That notwithstanding, the level of risk investors are willing to undertake differ from one person to the other which primarily depends on individuals' attitudes to risk (Jagongo \& Mutswenje, 2014; Ishfaq \& Anjum, 2015). According to (Farayibi, 2015), investors can be categorized into three namely risk averse, risk neutral and risk-seeking. The utility-to-wealth function for each category of investors is depicted in Figure 3.

According to Figure 3, a risk-averse investor attaches decreasing utility to each increment in wealth; a risk-neutral investor attaches equal utility to each increment in wealth; while a risk-seeking investor attaches increasing utility to each increment in wealth (Peirson et al., 2009). (Ishfaq \& Anjum, 2015) further explain the nature of the utility functions for each type of investor as illustrated in Figure 3:

i) Linear utility function: This is a characteristic of risk neutral investors. Linear utility function indicates that investors choose investments strictly on the basis of returns. A risk neutral investor will be indifferent to an investment with a fair return but highly risky. Thus the marginal utility of an additional investment made is constant irrespective of the amount of money the individual already has.

ii) Concave utility function: This function also known as diminishing marginal utility relates to risk-averse investors. The diminishing marginal utility means that the 


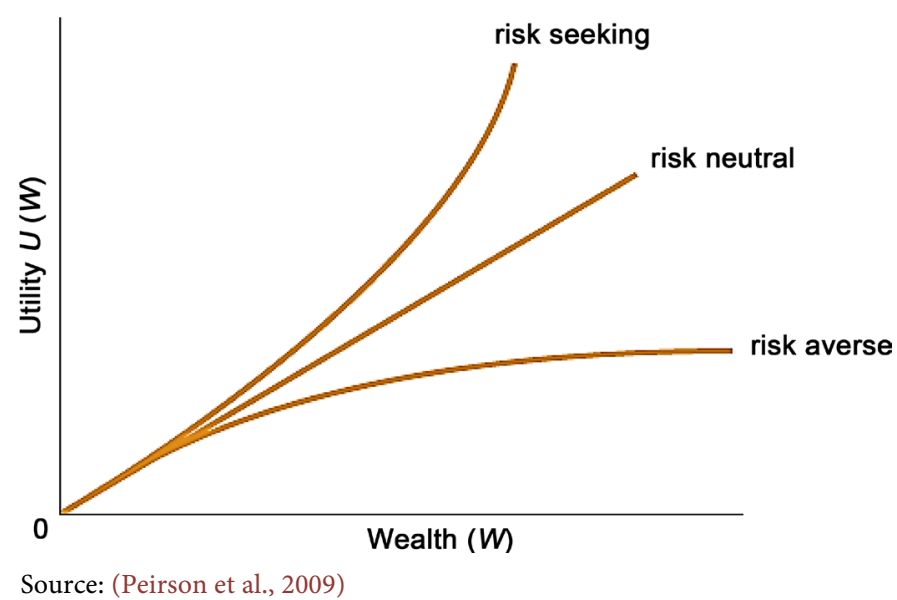

Figure 3. Utility-to-wealth function for different types of investors.

marginal utility of an investment is less than the utility of its return that is, the expected monetary value of the investment which is disincentive for risk-averse investors. Therefore, these types of investors are not interested in risky investments.

iii) Convex utility function: This function relates to risk-seeking investors who are considered as risk takers and often possess increasing marginal utility. These investors are willing to choose a highly risky investment but with a high return. Risk-seeking investors are not risk-pushovers even in the presence of high risks when making investment decisions.

The cost or fees of investment known as transaction cost is also consideration factor for taking investment decisions. Every investment product or service commands cost like any other commodity purchased. According to (Barber \& Odean, 2011), transaction costs are an unambiguous drag on the returns earned by individual investors and therefore shapes investors' behavior. (Wasik, 2013) likens the impact of transition costs on investment portfolios to wind, sun and rain pounding on painted wood over time which will culminate into a lot of damage to the wood. The most salient effect of transaction costs on investor behavior is the creation of a "no trade zone" around the optimal portfolio allocation, inside of which investors will not respond to changes in expected asset returns by rebalancing their positions, because the net gain from doing so is less than the transaction cost incurred (Matheson, 2011). Publication by (Securities and Exchange Commission, 2014) reveals that transaction cost may seem small but over time they can have a major impact on investment portfolio of investors. An illustration of how transaction costs affect investment portfolio is displayed in Figure 4.

Figure 4 illustrates how an investment portfolio with a $4 \%$ annual return over 20 years when the investment either has an ongoing fee of $0.25 \%, 0.50 \%$ or $1 \%$. In 20 years, $0.50 \%$ annual fees reduce portfolio value (red line) by $\$ 10,000$ compared to a portfolio with a $0.25 \%$ annual fee (blue line). Similarly, $1.00 \%$ annual fees reduce portfolio value (green line) by nearly $\$ 30,000$, compared to a portfolio with a $0.25 \%$ annual fee (blue line). 


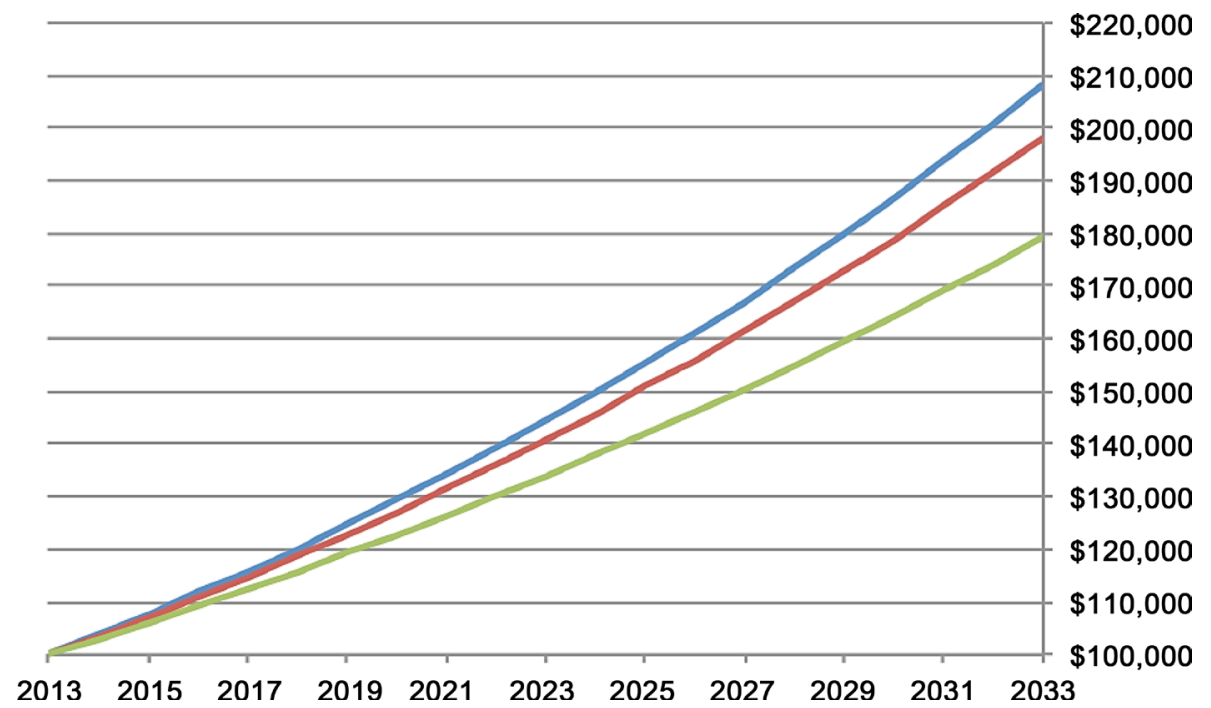

Note: Blue line $=4 \%$ annual return less $0.25 \%$ annual fees, Red line $=4 \%$ annual return less $0.50 \%$ annual fees, Green line $=4 \%$ annual return less $1.00 \%$ annual fees. Source: (Securities and Exchange Commission, 2014)

Figure 4. Portfolio value from investing $\$ 100,000$ over 20 years.

\subsubsection{Behavioral Pitfalls}

Emotions of investors may lead them in taking haphazard investment decisions. The underpinning factor for such decisions is usually associated with miscalculating risk tolerance and asset location. Thus, investors must understand the nature of behavioral pitfalls and how their decisions are affected by them in order to make prudent investment decisions. According to (Haritha \& Uchil, 2016), the major behavioral pitfalls of investors are ambiguity aversion, active trading, and familiarity biases.

\section{1) Ambiguity aversion}

Ambiguity aversion is a behavioral finance term that refers to the fact that people tend to prefer risk to ambiguity or uncertainty (Trautmann et al., 2008). Risk refers to events for which the probabilities of the possible outcomes are known, while ambiguity refers to events for which the probabilities of the possible outcomes are unknown (Dimmock et al., 2013). (Ellsberg, 1961) shows that people usually prefer risk rather than ambiguity, and defines an ambiguity-averse individual as one who prefers a lottery with known probabilities over a similar lottery with unknown probabilities. Investors' financial decision making can be influenced by ambiguity aversion. The first non-laboratory empirical study conducted in US by (Dimmock et al., 2013) reveals that ambiguity aversion is significantly and negatively associated with stock market participation and portfolio allocation to stocks. A study by (Antoniou et al., 2014) also establishes a negative relationship between stock market participation and ambiguity aversion. According to (Keller et al., 2007), the evidence on ambiguity aversion has been mixed. (Raiffa, 1961) argues that a rational decision maker should not be ambiguity averse. (Fox \& Tversky, 1995) find that ambiguity aversion disappears when individuals evaluate a single gamble (in a non-comparative setting), and (Chow \& Sarin, 2001) find that ambiguity aversion is reduced when making separate evaluations. Moreover, (Sarin 
\& Weber, 1993) argue that, in market settings, ambiguity aversion is reduced in independent auctions but not in simultaneous auctions.

\section{2) Active trading}

Active trading considered as one of the most speculative trading strategies seeks to take advantage of short-term movements in price, and often focuses on financial instruments in higher demand, such as ciurrencies, stocks, options, and derivatives (Haritha \& Uchil, 2016). The principal factor that accounts for active trading is overconfidence (Byrne \& Utkus, 2013). Investors with too much confidence in their trading skill often trade too much but earn the lowest returns (Barber \& Odean, 2000). (Odean, 1998) supports this assertion by arguing that overconfident investors trade more than rational investors and that doing so lowers their expected utilities. Overconfidence increases trading activity because it causes investors to be too certain about their own opinions and to not consider sufficiently the opinions of others (Barber \& Odean, 1999). (Barber \& Odean, 1999) further postulate that overconfident investors also perceive their actions to be less risky than generally proves to be the case. The result is an increase in the heterogeneity of investors' beliefs, and as (Harris \& Raviv, 1993) and (Varian, 1989) point out, heterogeneous beliefs are needed to generate significant trading. (Elan, 2010) highlights that active trading correlates with overconfidence and therefore a negative relationship exist between active trading and returns of investment. In an attempt to empirically establish that active trading leads to low returns, (Barber \& Odean, 1999) partitioned 78,000 households used for the study into quintiles on the basis of the average monthly turnover of their common stock portfolios. Mean monthly turnover for these quintiles ranged from $0.19 \%$ (the low-turnover quintile) to $21.49 \%$ (the high-turnover quintile). Households in the high-turnover quintile earned a net annualized geometric mean return of $11.4 \%$; households in the low-turnover quintile earned $18.5 \%$. Table 2 provides summary of these results generated by the study.

The annual net return earned by each household was compared with the annual net return that would have been earned had the household's beginning-of-the-year portfolio been held for a year without any trading, which is a reasonable measure of the impact of trading on returns. These bases of comparison were chosen by the authors because the households in each quintile could (and did) vary as to the average risk characteristics of their portfolios. The quintile of households that traded most infrequently underperformed its counterpart buy-and-hold portfolio by, on average, a mere $0.25 \mathrm{pps}$ annually, whereas the quintile of households that traded most frequently underperformed its counterpart buy-and-hold portfolio by, on average, a whopping 7.04 pps annually (Barber \& Odean, 1999). Based on the analyses from the study, (Barber \&

Table 2. Portfolio turnover and return.

\begin{tabular}{lcc}
\hline & Mean Monthly Turnover & Average Annual Portfolio Return \\
\hline $20 \%$ least active traders & $0.19 \%$ & $18.5 \%$ \\
$20 \%$ most active traders & $21.49 \%$ & $11.4 \%$ \\
\hline
\end{tabular}

Source: (Byrne \& Utkus, 2013). 
Odean, 1999) concluded that the more investors trade, the more they reduce their expected returns which is consistent with the prediction that overconfident traders earn less when they engage in active trading. The relationship between overconfidence and active trading illustrated graphically in Figure 5. According to Figure 5, overconfidence of investors leads to decrease in herding behavior. Herding behavior results in investors following or taking the opinions of some group of people into account in their investment decisions. However, overconfident investors are very certain about their own opinions and ignore the opinions of others, thereby reducing their herding behaviors. Overconfidence also results in increase in heterogeneity of investors' beliefs. The decrease in herding behavior and increase in heterogeneity of investors' beliefs caused by investors' overconfidence stimulates active trading which leads to low returns or decrease in returns on investors' investments.

\section{3) Familiarity biases}

Familiarity bias is directly derived from the founding behavioral work of (Kahneman \& Tversky, 1979). Familiarity bias is another shortcut the mind uses to filter information and make decisions which consists in the tendency to believe in and prefer things that are already familiar to us (Abreu, 2014). According to (Fox \& Tversky, 1995) when people are offered two alternatives, they prefer the one that they are familiar with. People tend to apply this analogy to stock selection decision in the sense that they are better informed about the securities that they are familiar compared to the ones that they are not (Chew et al., 2012). (Huberman, 2001) is of the opinion that due to preference for familiar and distaste for and fear from unfamiliar leads to the basic result that people simply prefer to invest in familiar securities. People have the belief that a familiar company is actually better and that investment in it has a lower risk and/or higher yield returns (Abreu, 2014). This explains investors' behavior as to their preference for investing in home markets to foreign markets. This is evident in a study by (Strong \& $\mathrm{Xu}, 2003)$ who found that investors are more optimistic towards their home markets

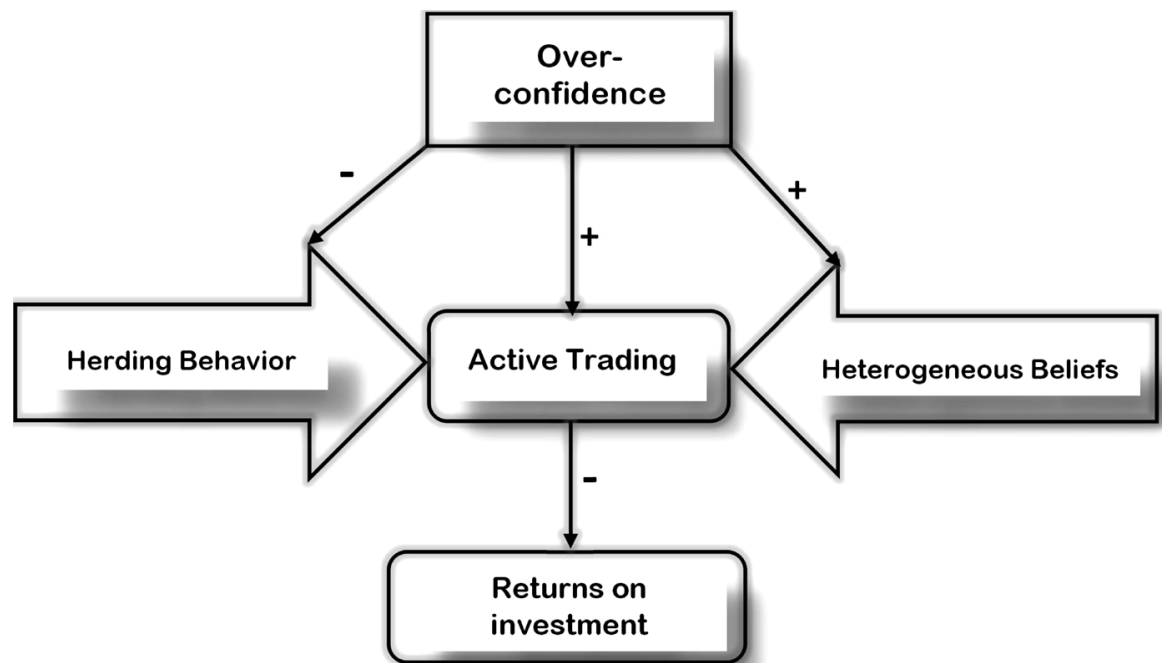

Source: Authors' construct

Figure 5. Relationship between overconfidence and active trading. 
than they are about foreign markets. (Chan et al., 2005) examined how mutual funds from 26 developed and developing countries allocate their investment between domestic and foreign equity markets and what factors determine their asset allocations worldwide. The study found a robust evidence that the funds, in aggregate, allocate a disproportionately larger fraction of investment to domestic stocks. Familiarity bias underscores the reason why people also invest enormously in the companies they work for (Elan, 2010). Several studies have been conducted in portraying and explaining workers' preferences in investing in their companies as well as in their own countries (Benartzi \& Thaler, 1995; Benartzi, 2001; Mitchell \& Utkus, 2002; Muelbroek, 2002). Portraying a bias toward familiar is an indicative of lack of diversification and can lead investors into losing their investment (Foad, 2010). (Tanner, 2015) provides a case study (Enron scandal) as an example of investors' investments been wiped out because of familiarity bias. According to (Tanner, 2015), executives and accountants of Enron were manipulating the books to make the firm seem vastly more successful than it was. When it all came to light, the company collapsed into bankruptcy in 2001. Employees with significant amounts of now-worthless Enron stock in their 401(k) plans suddenly weren't sure they could ever retire. One employee in his mid-50s at the time saw his retirement account drop from $\$ 470,000$ to $\$ 40,000$. Loses incurred would have been insulated if the investors had diversify their investments into less familiar assets. Familiarity bias can therefore be summarized as people's tendency to gravitate towards investments that are proximate with respect to location, occupation, or language and loses can be mitigated through diversification into other unfamiliar local and international securities (Seiler et al., 2007; Verma, 2016).

In the nutshell, all the aforementioned literature reviewed is an indication that investing decisions as well as stock market participation is very complicated. Therefore, a holistic consideration must be given to all factors that have the tendency of affecting investment decisions as well as the entire stock market. It is very imperative for investors to know that some of the factors that drive investors to be responsive to new events or information are interrelated. Thus, such financial knowledge will be a catalyst for investors to avoid being pushed into behavioral pitfalls by their own decisions which may cause them to lose part or whole of their investments. An interrelated conceptual framework of the drivers of investors' decisions and stock markets' reaction to new event has been designed by the authors in order to help investors make optimal investment decisions. The interrelated conceptual framework depicted in Figure 6 shows that stock markets' reaction are driven by company fundamentals, technical factors and market sentiments as well as the interrelation between them.

\section{FEATURES OF THE FRAMEWORK}

The features of the framework are illustrated by the individual arrows defined by the alphabets (A) to (J):

i) A and B represent the influence of technical factors on stock markets to react to new events or information such as natural disasters, wars, government policies, political events, money supply, interest rate, exchange rate, inflation, etc. 


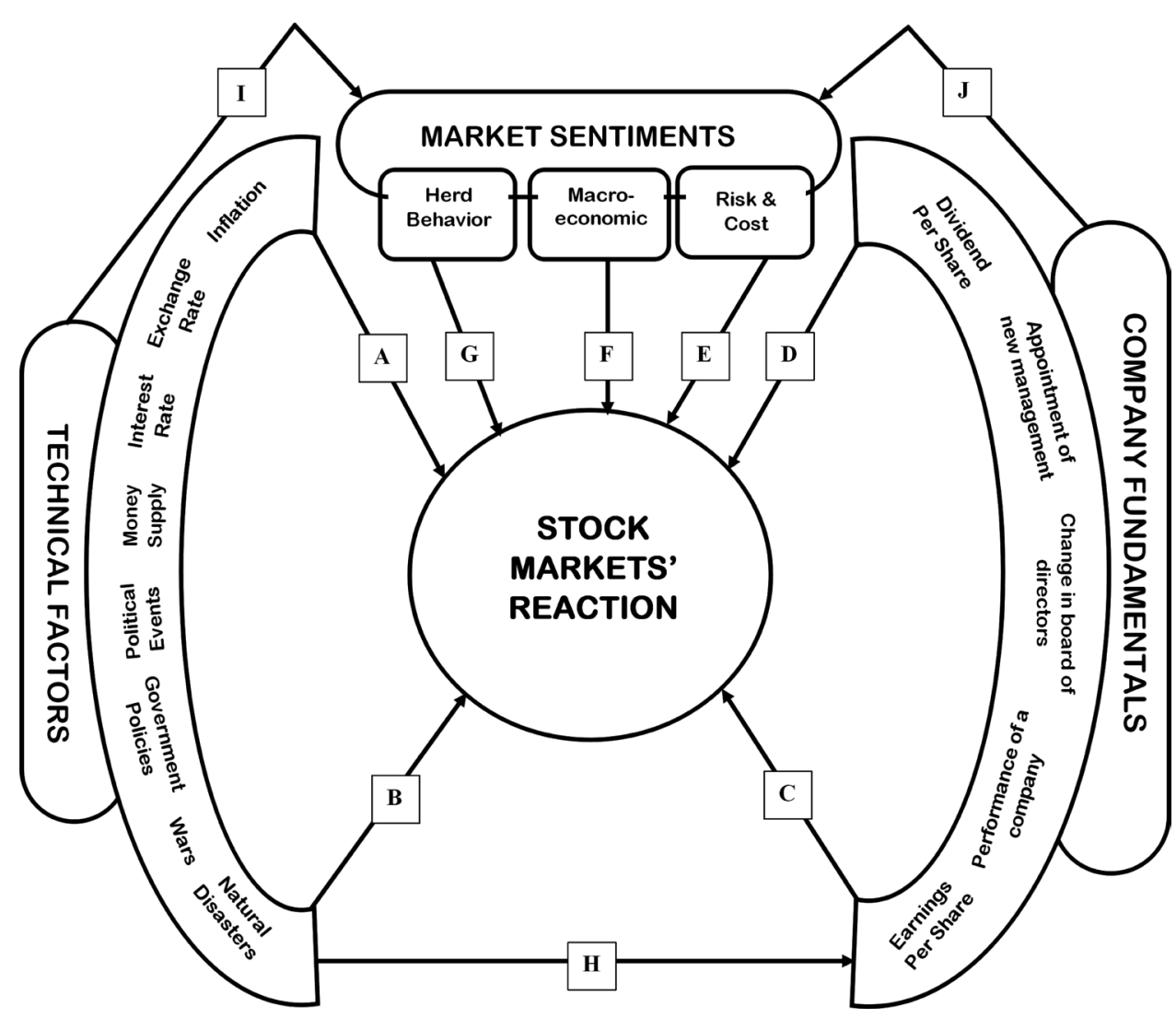

Source: Authors' Construct

Figure 6. Interrelated conceptual framework for stock markets' reaction to new events.

ii) C and D represent the influence of company fundamentals on stock markets to react to new events or information such as earnings per share, performance of a company, dividend per share, change in board of directors, appointment of new management, etc.

iii) E, F and G represent herd behavior, macroeconomic and risk \& cost respectively as some of the components of market sentiments that drive stock markets to react to new events or information.

iv) $\mathrm{H}$ represents the interrelation between technical factors and company fundamentals. The arrow $\mathrm{H}$ is an indication of the effect of technical factors on some company fundamentals. Technical factors like natural disasters, wars, government policies, political events, money supply, interest rate, exchange rate, inflation, etc. have a great potential of positively or negatively affecting shareholders wealth of companies and their overall successes. Company fundamentals such as performance of a company, earnings per share and dividend per share as shown in Figure 6 will be affected by some technical factors which will influence the decision making of investors.

v) I represents the interrelation between technical factors and market sentiments. The arrow I shows the effect of technical factors on market sentiments. Some technical factors like natural disasters, wars, political events, government policies, interest 
rate, exchange rate and money supply in an economy may affect the psychology, emotions and sentiments of investors in the process of taking investment decisions.

vi) J represents the interrelation between company fundamentals and market sentiments. The arrow J depicts the influence of company fundamentals on market sentiments. Company fundamentals such as performance of company, earnings and dividends declaration, appointment of new management, change in board of directors, etc. may affect individuals' emotions and behavior which are elements of market sentiments.

According to Figure 6, technical factors, company fundamentals and market sentiments influence stock markets to react to new events or information. The framework also illustrates the interrelation between technical factors \& market sentiments, technical factors \& company fundamentals and company fundamentals \& market sentiments. This means that technical factors influence company fundamentals, company fundamentals influence market sentiments and technical factors influence market sentiments. Both technical factors and company fundamentals influence market sentiments which appeal to the emotions and psychology of individual investors. Consequently, it is very imperative for individual investors, financial analysts and the entire financial community to have a holistic and interrelated viewpoint of the drivers that influence their investment decisions and the stock market in general which will enable them to take optimal investment decisions. The framework in Figure 6 admonishes investors to avoid isolation consideration of the factors that influence their investment decisions in order to escape any behavioral pitfall as illustrated in Figure 1.

\section{Road to Brexit}

In January 2013 Britain's Prime Minister David Cameron committed to holding a referendum on EU membership which took place on June 23, 2016 (Reenen, 2016). Supporters of UK-leaving campaign christened as "Brexit" focused on the democratic benefits of repatriating powers back from Brussels whiles supporters of the UK-remaining in EU argued that the EU reduces the risk of conflict and makes Britain stronger on the world stage (Dhingra et al., 2016). The results of the referendum favored advocates of Brexit (Riley \& Long, 2016b). Douglas Webber, Professor of Political Science at European Institute for Business Administration known as INSEAD provides the following account of the road leading to Brexit (Webber, 2016):

The UK was a latecomer to the EU. The English Channel, that thin stretch of water, no more than $32 \mathrm{~km}$ wide at its narrowest point, has enabled the country to avoid foreign invasion and occupation for almost 1000 years. Historically the UK steered clear of deep and permanent engagement on the European mainland, intervening primarily when, as in the cases of Napoleonic France and imperial and Nazi Germany, a single power threatened to achieve hegemonic control of continental Europe. Following the Second World War, closely allied with the US and at the hub of the (British) Commonwealth, the UK aspired to play a world role as an independent state. It initially stayed out of both the European Coal and Steel Community (ECSC), founded in 1950, 
and the European Economic Community (EEC), launched in 1957. By the time it changed its mind, for economic reasons, in the $1960 \mathrm{~s}$, the French president Charles de Gaulle was in power and twice vetoed British entry. When the UK finally entered the $E U$, after De Gaulle stepped down, in 1973, it remained an ambivalent member. A new Labour government renegotiated the UK's accession terms in 1974-75 and called a popular referendum that produced a two-to-one majority in favour of staying in. The $U K ' s$ relations with the EU nonetheless remained fraught, as illustrated by the decade-long conflict over its contribution to the EU budget (resolved at an historic summit at Fontainebleau in 1984).

Following the end of the Cold War, as the rest of the EU began to forge closer political integration, the UK increasingly became a semi-detached member. It opted out of the Euro, the (borderless) Schengen Area and-initially-the social policy provisions of the Maastricht Treaty. In 1992, the pound was unceremoniously ejected from the European Monetary System (EMS), which it had entered only in 1989-an event that the Conservative government of the time experienced as a brutal humiliation (such that the Chancellor of the Exchequer who supported EMS entry in the late 1980s, Nigel Lawson, has meanwhile become a leading advocate of Brexit).

\section{Political Drivers of Brexit}

In the last 25 years, Euroscepticism changed political camps in the UK. While Labour, which had proposed to leave the EU in the early 1980s, became more 'pro-European', the Conservatives, who had overwhelmingly supported EU accession in the $1970 \mathrm{~s}$, grew increasingly hostile. Along with the rise of the fiercely' anti-European' UK Independence Party (UKIP), the growth of Euroscepticism in the Conservative Party persuaded Cameron to pledge a (second) referendum on EU membership if his party won a majority at the 2015 Parliamentary elections-which, against all expectations, he did.

The final results of the referendum held on June 23, 2016 saw $51.9 \%$ of voters chose to leave the EU, while $48.1 \%$ wanted to remain (Riley \& Long, 2016b). Prime Minister David Cameron who led the remain-in-EU campaign resigned immediately after the results were released (Kottasova \& Petroff, 2016). According to (Morris, 2013), some of the issues which informed voters voting in favor of Brexit are: (i) Eurosceptics believe that trade with EU countries would not be much affected by an exit because UK's trade deficit with the EU provides enough bargaining power to allow the negotiation of a free trade agreement between the two parties, similar to that enjoyed by Norway or Switzerland; (ii) Britain would be able to expand its trade with non-EU countries through the negotiations of new trade agreements that would not be subjected to constraints imposed by other EU members; (iii) the UK country would be free from the regulatory burden and the costs associated with the EU membership (the EU budget is structured so that the UK consistently contributes a greater proportion of finances than it receives in return (Baimbridge, 2016), for instance, in 2015 the UK government paid $£ 13$ billion to the EU budget, and EU spending on the UK was $£ 4.5$ billion; therefore, the UK's "net contribution" was estimated at about $£ 8.5$ billion (Full Fact Team, 2016) as depicted in 
Figure 7). Figure 7 also illustrates the fact that UK has always been contributing more to EU's budget than what it receives from EU since they joined EU.

Another factor worthy of mentioning that worked in favor of Brexit was the issue of immigration. Eurosceptics oppose the flow of immigrants allowed to live and work in Britain which has become increasingly hard to control because of UK's membership with EU (Miles, 2016). Pro-Brexit supporters are of the view that high levels of immigration will hurt their jobs, wages and quality of life (Wadsworth et al., 2016). The number of immigrants from other EU countries living in the UK, according to (Reenen, 2016), tripled from 0.9 million to 3.3 million between 1995 and 2015. In 2015, EU net immigration to the UK was 172,000 comprising $257,000 \mathrm{EU}$ nationals arriving and 85,000 leaving which is, only just below the figure of 191,000 for non-EU immigrants and such net immigration is shown in Figure 8.

\section{Global Financial Effects of Brexit}

The arguments for EU-stay and EU-out heightened stakes amongst the various stakeholders of which the financial markets were not exempted. There were uncertainties in the minds of financial players as to the outcome of the referendum and how the outcome may or may not cause financial turmoil across the globe. Many financial analysts and political scientists predicted a close contest between the two factions. The results of the referendum: $51.9 \%$ for Brexit voters and $48.1 \%$ for EU remain affirmed their prediction. The results of the referendum caused "volcanic eruption" across the global financial markets a day after the referendum. This is because many people never expected this outcome. British business leaders warned for months that if UK voters chose to exile themselves from the EU, there would be swift, negative consequences and

\section{UK payments to EU budget}

\section{Balance of UK contributions to and public sector receipts from the EU budget, adjusted for inflation, calendar years}

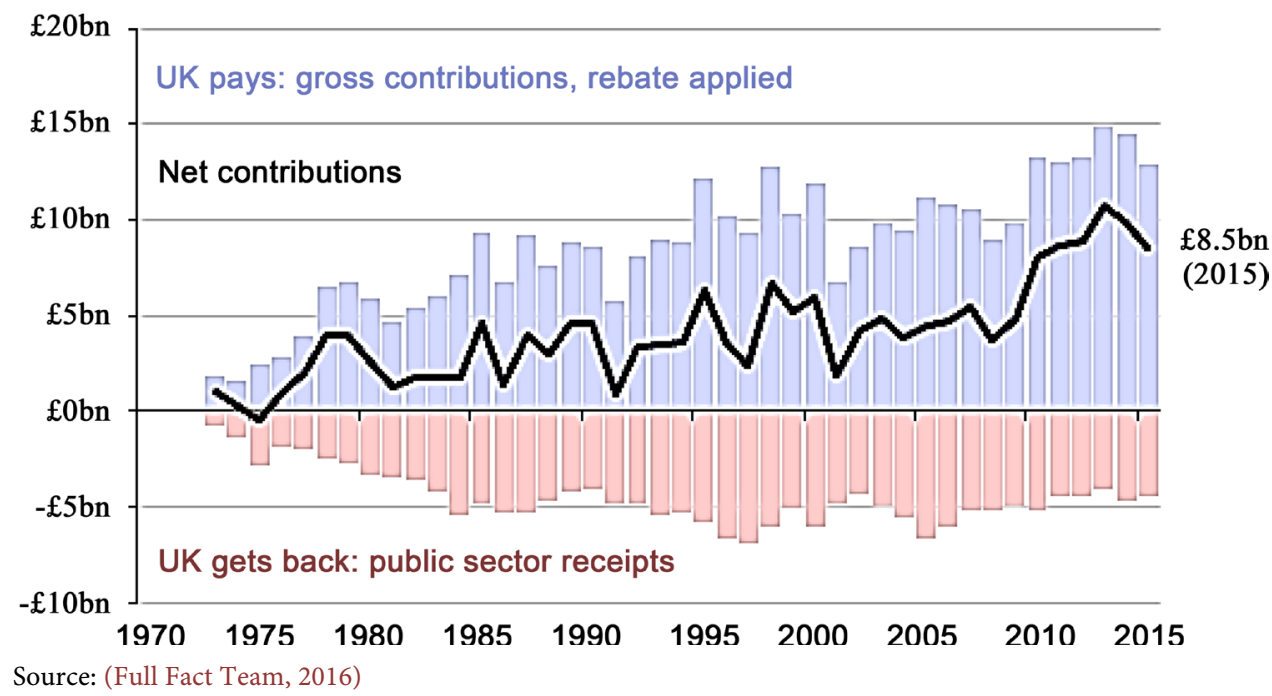

Figure 7. UK payments to EU budget. 


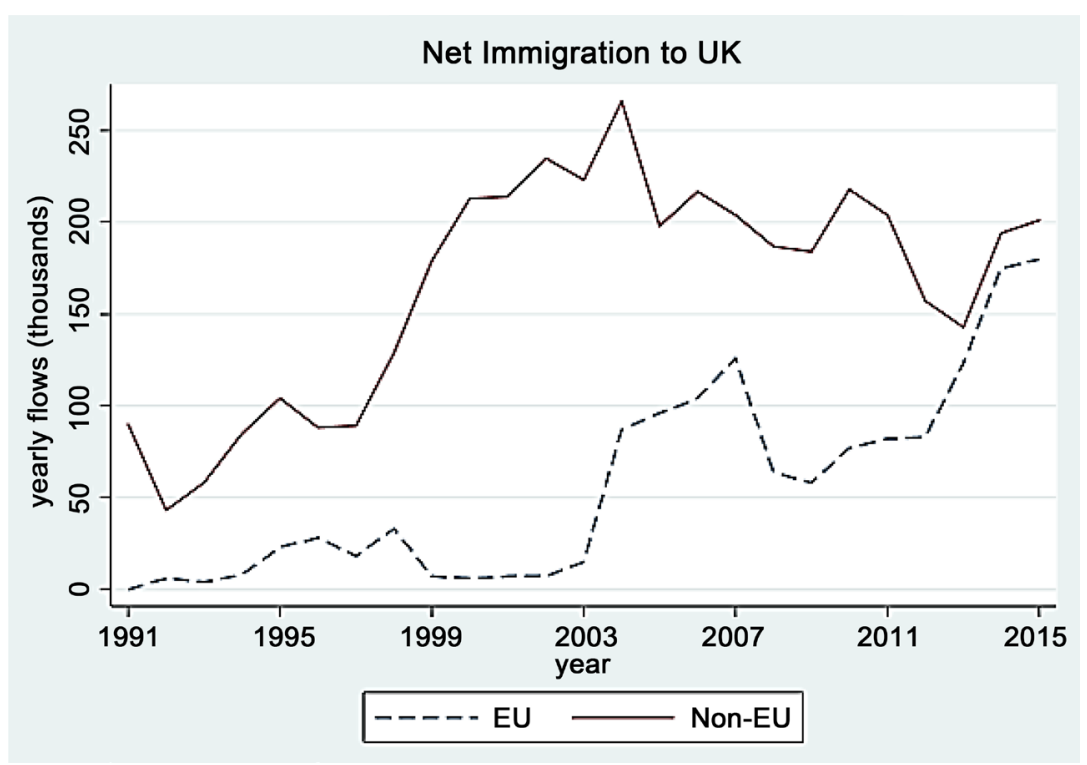

Source: (Reenen, 2016)

Figure 8. Net immigration to the UK, 1991-2015.

their fears were realized on Friday, June 24, 2016 (Riley \& Long, 2016a) which is evident by the following statements:

"Everybody's obviously a little bit stunned," said Andrew Sullivan, managing director of sales trading at Haitong International Securities in Hong Kong (Mullen, 2016);

"I think markets were really caught off guard today, that's why you are seeing a huge risk-off trade," said Jeff Kravetz, a strategist at the Private Client Reserve at US Bank (Lash \& Krudy, 2016);

"The financial markets have certainly taken the view that the decision to leave the European Union is bad news for the United Kingdom in the near term at least," said Howard Archer, chief economist at IHS (Kottasova \& Petroff, 2016);

"P $m$ afraid that this is not such a good day for Europe," said Deutsche Bank (DB) CEO John Cryan, "at this stage, we cannot fully foresee the consequences, but there's no doubt that they will be negative on all sides" (Yan, 2016).

These explain the intense shock waves that went through the spines of global investors as a result of the financial turbulence caused by Brexit's win. Barely 24 hours after the results were declared, global stock markets lost about $\$ 2$ trillion in value (Lash \& Krudy, 2016). Breakdown of how the various financial markets and sectors of the world's economies were affected a day after UK voted to leave the EU are captured in the subsections of this chapter.

\subsection{Currencies}

The British pound plunged to almost $\$ 1.33$, its lowest level in over 30 years against the U.S. dollar as the results of the referendum became clear (Mullen et al., 2016; Riley \& Long, 2016b). Its decline comfortably eclipsed that of Black Wednesday in 1992, when the UK left the Exchange Rate Mechanism (Mackenzie \& Platt, 2016). The euro also fell 


\section{Currencies Plummet}

1 British pound in dollars

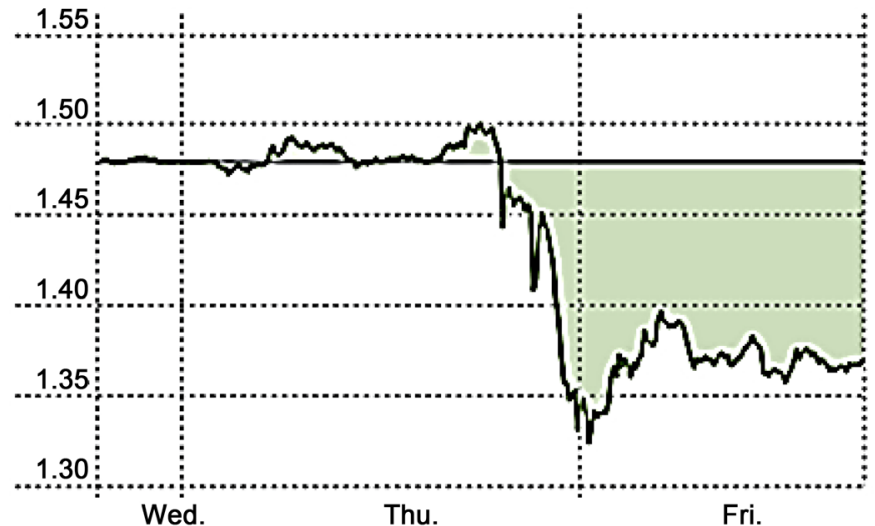

Source: (Russell \& Lee, 2016)

Figure 9. Currencies plummet.
At market close 06/24/2016

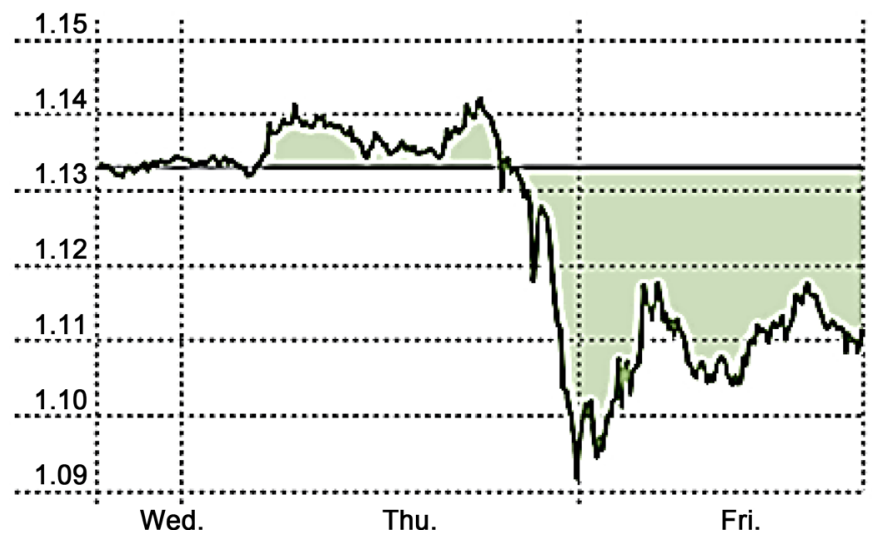

heavily (Mullen et al., 2016). The plummeting of the British pounds and the euro against the US dollar is illustrated in Figure 9.

The likelihood of increase in risk aversion among investors following the referendum's results also caused emerging markets to suffer as the US dollar rallied. The South African rand, the Polish zloty and Mexican peso were down more than 3\% (Mackenzie \& Platt, 2016) and the value of the Ghana cedi recorded a marginal plunge of $1.04 \%$ on the interbank foreign exchange market (Lokko, 2016). Some currencies were safe havens for investors which included the Japanese yen, the Swiss franc and even Bitcoin (Mullen et al., 2016; Riley \& Long, 2016b). According to (Mackenzie \& Platt, 2016), the yen soared as much $6.7 \%$ to $¥ 99.02$ at the worst of the fallout in currency markets.

\subsection{Stock Markets}

The FTSE 250, which is made up of mostly mid-sized British companies, plummeted 7.2\% (Riley \& Long, 2016a). Many analysts see the FTSE 250 as a more accurate reflection of the British economy because it tracks firms that do more of their business inside Britain (Kottasova \& Petroff, 2016). US stocks followed plunging global markets. The Dow ended the day down 611 points, or over $3.4 \%$ while the Nasdaq composite index dropped $4.12 \%$, and into correction territory-or down $10 \%$ from its recent high (Mullen \& Platt, 2016). The FTSE 100 ended the day 3.2\% lower and The S\&P 500 fell 3.6\%, its biggest one-day drop since August-leaving it below where it finished 2015 (Mackenzie \& Platt, 2016). A broad gauge of European blue-chip stocks index sank around 6.7\% and the Hang Seng in Hong Kong dropped 2.9\% (Mullen et al., 2016). Euro Stoxx 600, a major gauge of stocks across the continent, closed down 7\% (Mackenzie \& Platt, 2016). (Mackenzie \& Platt, 2016) also reveals that Japan's Topix closed 7.3\% lower and the Nikkei 225 fell 7.9\% while in Australia, the ASX index settled down $3.2 \%$. Germany's DAX index and stocks in Ireland dropped by nearly $7 \%$ and $8 \%$ 
respectively, while the French CAC plunged by $8 \%$ (Kottasova \& Petroff, 2016). Italian's FTMIB and Spanish's IBEX markets posted their sharpest one-day drops ever, falling more than $12 \%$, led by a dive in European bank stocks SX7P; moreover, Italy's Unicredit (CRDI.MI) fell 24\% while Spain's Banco Santander (SAN.MC) fell 20\% (Lash \& Krudy, 2016). Utility stocks, generally considered less geared to the global economy with relatively stable cash flows and debt profiles, defied the wider drop to climb $0.1 \%$ (Mackenzie \& Platt, 2016). The changes in prices of some of the global stock markets affected by the results of the referendum by the close of trading on June 24, 2016 are summarized in Figure 10.

\subsection{Banks}

Banking shares across Europe were crushed. Barclays plummeted 17\% in London trading, Royal Bank of Scotland (RBS) tumbled 17\%, Lloyds Bank nosedived 19\%, Germany's Deutsche Bank dropped 14\%, shares of the UK's biggest bank, HSBC (HSBC) in Asia crashed 7\%, while Standard Chartered (SCBFF), a British bank that focuses

\begin{tabular}{|c|c|c|c|c|}
\hline \multicolumn{5}{|l|}{ Americass } \\
\hline Neme $A$ : & 20 oys & Last. & NetChng & \&Chng: \\
\hline 樽 ES\&P 5000 & & $2,037.41$ & -75.91 & $-3.59 \%$ \\
\hline : \&DI & & $17,400.75$ & .610 .32 & $-3.39 \%$ \\
\hline 国 \& NASDAQ 100 & & $4,285.70$ & -181.78 & $-4.07 \%$ \\
\hline IA SAPISXO & & $13,891.88$ & 239.50 & $-1.69 \%$ \\
\hline S BOVESPAO & & $50,105.26$ & $-1,454.56$ & $-2.82 \%$ \\
\hline IVI \& MXSEIPCO & & $44,885.82$ & $-1,260.10$ & $-273 \%$ \\
\hline \multicolumn{5}{|l|}{ Europes } \\
\hline Name - & 2 Days & Lost & Net Ching & \& Chng \\
\hline B] : STXE 6000 & & 321.98 & -24.36 & $-7.03 \%$ \\
\hline 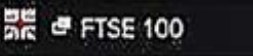 & & $6,138.69$ & -199.41 & $.3 .15 \%$ \\
\hline$=$ O DAXO & & $9,557.16$ & .699 .87 & $-6.82 \%$ \\
\hline III $\triangle \mathrm{CAC} 400$ & & $4,106.73$ & .359 .17 & $-8.04 \%$ \\
\hline III II FISEMIB & & $15,723.81$ & -2.242 .36 & $.12 .48 \%$ \\
\hline I I smio & & $7,747.18$ & -275.87 & $-3.44 \%$ \\
\hline$=$ AEXO & & 424.20 & -25.66 & $-5.70 \%$ \\
\hline 플 BBEXO & & $7,787.70$ & $-1,097.60$ & $-12.35 \%$ \\
\hline F OMXs 30 & wotv & $1,360.73$ & 6.13 & $0.45 \%$ \\
\hline \multicolumn{5}{|l|}{ Asla $>$} \\
\hline Name $\triangle$ & 20 osys & Last & Net Chng & \% Ching \\
\hline 이 NIKKEI 225 & & $14,952.02$ & $-1,286,33$ & $-7.92 \%$ \\
\hline DS SRPIASX 200 & & $5,113.18$ & -167.50 & $-3.17 \%$ \\
\hline [3] HANG SENGO & & $20,259.13$ & .609 .21 & $-2.92 \%$ \\
\hline
\end{tabular}

Source: (The Guardian, 2016)

Figure 10. Global stock markets reaction to Brexit win after Trading on June 24, 2016. 
on Asia, lost 9\% in Hong Kong trading (Yan, 2016). US banks also got hit, feeling the downsides of the American-British "special relationship." Morgan Stanley (MS) fell over 10\%, Citigroup (C) slid over 9\% and Goldman Sachs (GS) was down 7\% (Riley \& Long, 2016a). (Riley \& Long, 2016a) further reports that Invesco (IVZ), an investment firm headquartered in the US but with a substantial presence in the UK was the worst performer in the entire S\&P 500, falling nearly 14\%. The Euro Stoxx Banks index plunged 18\% which was its worst ever drop (Mackenzie \& Platt, 2016).

\subsection{Automakers and Home Builders}

Ford (F), which has nearly 14,000 workers in the UK, fell over 6.5\%; companies that make car parts like BorgWarner (BWA) and Delphi Automotive (DLPH) tanked about 10\% each while Travel site Priceline (PCLN, Tech30), which has a lot of revenue coming from Europe, fell over 11\% (Riley \& Long, 2016a). Homebuilder Taylor Wimpey (TWODF) had its shares dropped by more than 29\% (Kottasova \& Petroff, 2016). Stocks of airline EasyJet (ESYJY) was slammed as it fell over 14\% on Friday June 24, 2016 and American Airlines (AAL) (a partner with British Airways) lost over 10\% (Riley \& Long, 2016a).

\subsection{Commodities}

As the financial markets were being tattered by the referendum results, investors poured money into perceived safe havens. It was a good day for gold investors, with the metal rising as much as $8.1 \%$ before easing back to just over the $\$ 1300$-an-ounce mark, which was still up nearly $5 \%$ on the day (June 24, 2016) (Mackenzie \& Platt, 2016). In the view of (Mackenzie \& Platt, 2016), Gold has been one of the best performing financial assets of the year even before Brexit, and is up $24 \%$ for the year. The rise of gold price during Friday's, (June 24, 2016) trading is shown in Figure 11.

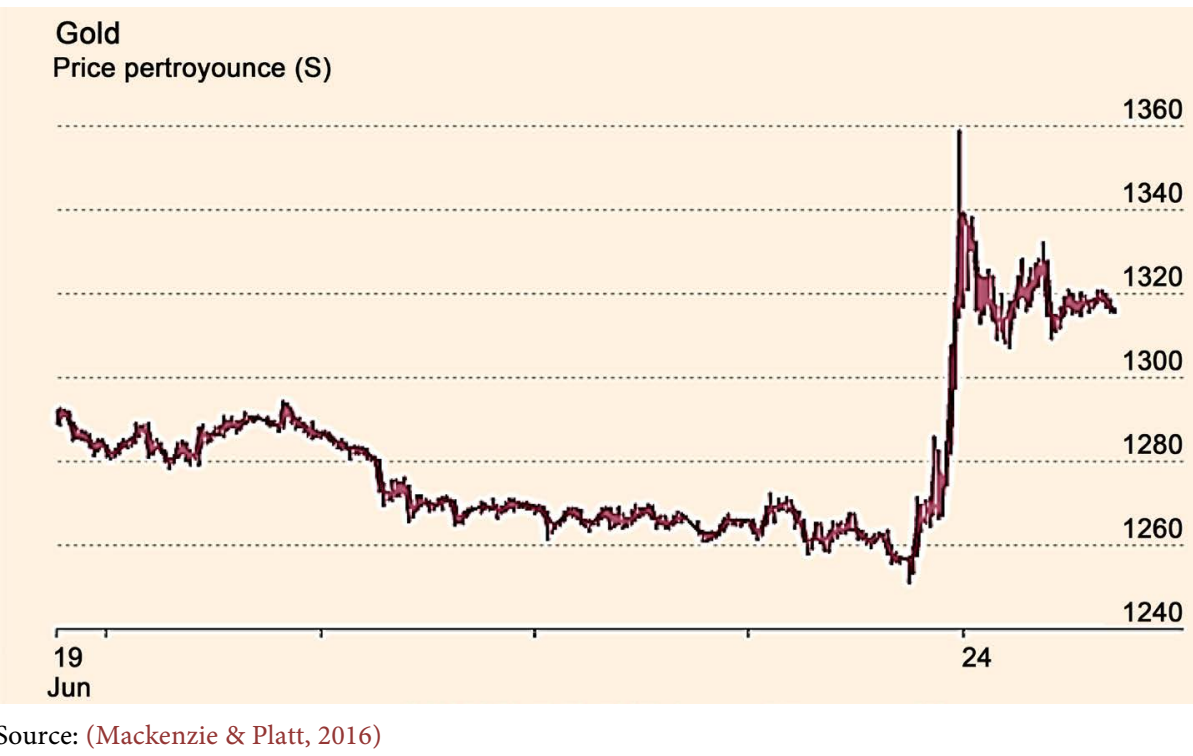

Figure 11. Rise of gold price a day after brexit referendum. 
Oil prices slumped around 5\% amid fears of a broader economic slowdown that could reduce demand. US crude CLc1 shed $\$ 2.51$ to $\$ 47.60$ a barrel while Brent LCOc1 fell 4.9\% to \$48.42. Industrial metal copper CMCU3 sank 1.7\% (Lash \& Krudy, 2016).

\subsection{Bonds}

The bond market was one of the avenues of comfort for investors. (Mackenzie \& Platt, 2016) highlights how the bond market reacted to the Brexit event in four countries. US Treasuries, the anchor for the global financial system, with the yield on the 10-year note fell more than 30 basis points (bp) to $1.40 \%$, its lowest level since 2012 . The yield which is a benchmark for corporate borrowing costs in the US eased back to $1.56 \%$ in late afternoon trading on Wall Street on June 24, 2016. The reaction of the US 10-year Treasury to the Brexit's win is displayed in Figure 12. The 10-year UK Gilt yield fell to a record low of $1.02 \%$, a decline of $35 \mathrm{bp}$, as investors expect easing and additional liquidity from the Bank of England but slipped back to close at 1.08\%. The German 10-year Bund yield hit a record low of minus $0.18 \%$ as peripheral yields rose sharply, led by a $35 \mathrm{bp}$ rise in Portugal's 10-year yield to $3.4 \%$. The Portuguese note finished at $3.31 \%$ as the market calmed.

\subsection{Hedge Fund}

A report by (Johnson et al., 2016) reveals how the hedge funds performed on June 24, 2016. Hedge funds betting that Britain would leave the EU were rewarded with bumper payouts after stock markets fell sharply on the back of the Brexit decision. The heavy fall for UK and European stocks after the release of the results of the referendum led to gains for some of the most bearish hedge fund managers such as Crispin Odey, who was among those that had been previously nursing large losses for the year. Stockpicking hedge funds including Marshall Wace, Odey Asset Management and TT Inter-
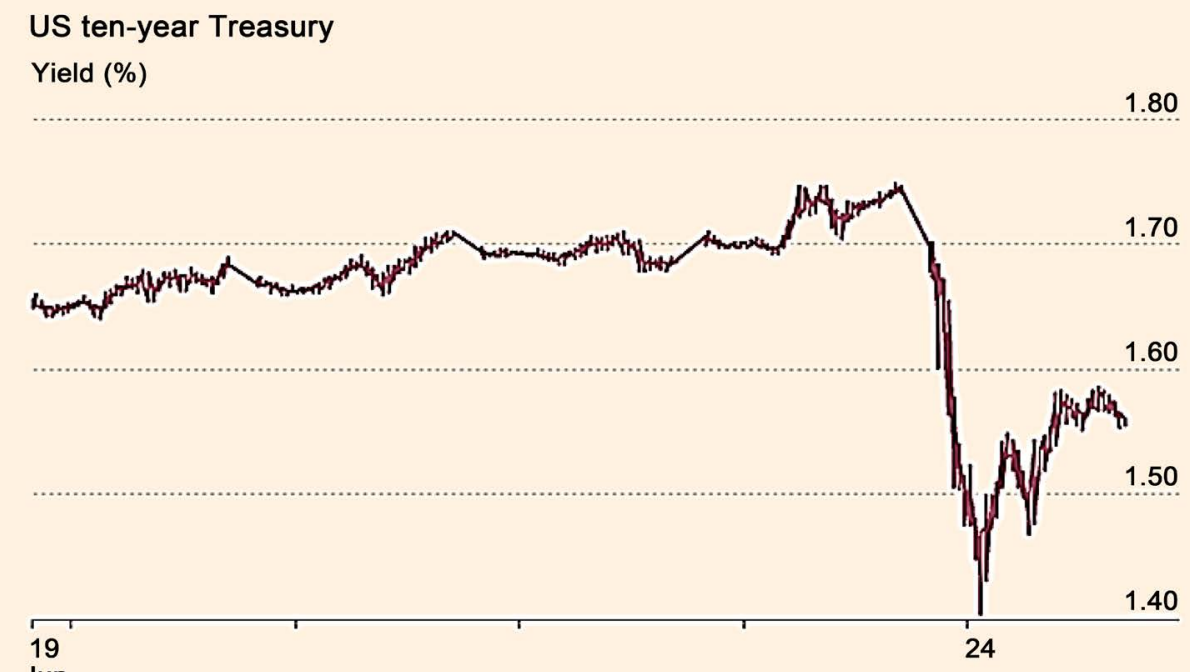

Jun

Source: (Mackenzie \& Platt, 2016)

Figure 12. US ten-year treasury reaction to brexit referendum. 
national were some of the biggest names to make money on their short positions against UK stocks. Hedge funds that had taken short positions against equities but bought bonds also benefited on the first day of trading after the Brexit vote, including Winton Capital Management and Aspect, which run computer-driven funds.

\section{Conclusion}

Events that cause financial turbulence are often not expected by investors and the entire financial markets. Their reaction to such events is evidence of shock and some throw up their hands in despair especially risk aversion investors. The Great depression, 9/11 terrorist attacks on US, the Great recession and Japanese earthquake in 2011 are some of events which caught financial experts and investors unaware and devastated savings as well as portfolios in a blink of the eye. These unexpected events have been named Black Swans by investors. The term, coined by professor and former derivatives trader Nassim Nicholas Taleb, refers to the rare or unexpected event which has profound economic or social consequences (Crumbaker, 2016). A Black Swan like Brexit which was far from unexpected should not have caused any financial "tsunami" on the financial markets because the referendum was first announced four months ago. Despite four months to prepare for this vote, the global financial community was nonetheless unprepared for the devastating effects of UK departure from the EU because it was largely predicted that the UK would vote to remain in the EU. The motivation of this paper is to review empirically from various literature with regards to the underlying factors that drive stock markets and the investing community in general to react to new events with Brexit as a case study. The Brexit like any other Black Swan event is likely to worsen and have long-lasting effects. However, this paper presents short-term, specifically a day's (June 24,2016 ) impact of Brexit results on the global financial markets. A significant effect of Brexit that can hardly be erased from the minds of global investing community is how the British pound lost in value to its lowest level in over 30 years against the US dollar. Stocks of several companies and stock markets' performances took a nosedive across the world as investors look on helplessly with their investments being eroded by Brexit results.

The result of the Brexit referendum is a demonstration to the fact that every investment has an element of real risk. Therefore, it is very imperative for investors to have a risk management plan which will minimize their loss during stock market volatility especially to prevent permanent loss of the capital invested. This paper will be beneficial to the investing community as it enlightens them not to allow themselves to be swayed always by the predictions of the majority with regards to some known future events like Brexit. This paper admonishes investors to sometimes think contrary when the predictions of majority of financial analysts and the investing community favour a particular outcome of an expected future event like Brexit. This may prevent partial or total investment loss if the actual result of the event contradicts investors' expectations. This research will also contribute enormously to existing literature about determinants of volatility of stock markets and individuals investment behaviors. Moreover, the interrelated conceptual framework for stock markets' reaction designed will close the gap in 
literature which deals with the interrelation among the categories of drivers of stock markets' reaction namely technical factors, company fundamentals and market sentiments. Thus, it is very vital for investors to have a holistic and interrelated analysis of the determinants of stock markets' reaction to new events in order to minimize the devastating effects of some black swans like Brexit. Moreover, (Sheldon, 2016) recommends four ways as protection mechanism in order to mitigate the impact of Black Swan events on investors:

\subsection{Diversify Properly}

When building a portfolio, it is important to ensure the portfolio is diversified at both an asset allocation level and also at stock level. The portfolio should not be exposed to any one asset class at asset allocation level. Unfortunately, many investors often suffer from "home bias" whereby they invest primarily in domestic equities, ignoring the diversification benefits of having international exposure. This can backfire in the event of a domestic downturn and investors with a high proportion of their portfolio in UK stocks will certainly be feeling the pain during the Brexit. Furthermore, at stock level, investors must ensure portfolio is properly diversified and not overexposed to specific stocks. The downside risk must always be taken into consideration when making investment decisions irrespective of their level of interest in a particular stock.

\subsection{The Power of Dividends}

Numerous studies have shown that dividends contribute a large part of total returns over the long term. For example, over the last five years the FTSE 100 has returned around $8 \%$ before dividends. Add-in reinvestment of the dividends and the return is closer to $30 \%$ which is a huge difference. For that reason, investors can readjust their investing strategy to focus more on dividends. While no one likes to see the capital values of their investments fall, there's no doubt that dividends provide a certain level of comfort during volatile times. The capital values should not be much of importance to a long-term investor in the short-term but would be compensated from receiving regular dividends and these dividends can be reinvested into the market.

\subsection{Avoid Overexposure}

It's important for investors to ensure that they are not over exposed to the share market. The temptation to be greedy during good times heightens which may lead to a huge risk, overexposure. The market can be extremely volatile and can hit the hardest when everyone least expects it. Therefore, investors are advised to only invest what they can afford to lose. For instance, if an investor is likely to need the funds in the short term for a house deposit or university fees, then share market is most likely not the best investment vehicle for such savings.

\subsection{Stockpile Cash}

It is financial prudent to always have some cash on the sidelines ready to deploy when 
opportunities arise. As many stocks fell $30 \%$ to $50 \%$ after the release of the Brexit results and the likelihood market volatility to persist, opportunities may will arise at some stage. Therefore, investors with cash available can take advantage of these opportunities.

\section{Future Research}

This paper presents a day's (June 24, 2016) impact of the financial turbulence caused by the Brexit referendum held on June 23, 2016. Other research works can focus on more short-term effects other than only a day's impact as well as long-term effects. This study also focused on the economic impact of Brexit but limited to stocks and the entire global financial markets. Political and social effects as well as effect of Brexit on other economic variables like unemployment, trade, foreign investments, etc. can be explored by other researchers. Some studies were conducted on these variables before the referendum (Hickson \& Miles, 2016; Reenen, 2016). Other research works can be conducted on these areas to ascertain the actual effects after UK voted to leave the EU. Further study can also be done using event study methodology to measure the abnormal returns that would accrue to investors on the various stock markets affected by the Brexit.

\section{References}

Abreu, M. (2014). Individual Investors' Behavioral Biases. Teaching Economics Working Paper No. TEWP 01/2014/DE/UECE. https://www.repository.utl.pt/bitstream/10400.5/7439/1/TEWP012014.pdf

Adam, A. M., \& Tweneboah, G. (2008). Macroeconomic Factors and Stock Market Movement: Evidence from Ghana. SSRN Electronic Journal, 1-26. https://doi.org/10.2139/ssrn.1289842

Agrawal, G., Srivastav, A. K., \& Srivastava, A. (2010). A Study of Exchange Rates Movement and Stock Market Volatility. International Journal of Business and Management, 5, 62-73. https://doi.org/10.5539/ijbm.v5n12p62

Akami, K., \& Slovic, P. (1994). A Psychological Study of the Inverse Relationship between Perceived risk and Perceived Benefit. Risk Analysis, 14, 1085-1096. https://doi.org/10.1111/j.1539-6924.1994.tb00080.x

Allen, D. E., Mcaleer, M., \& Singh, A. K. (2015). Daily Market News Sentiment and Stock Prices. ICAE Working Paper No. 1511. http://eprints.sim.ucm.es/33044/1/1511.pdf

Al-Tamimia, H. A. H., Alwana, A. A., \& Rahmana, A. A. A. (2011). Factors Affecting Stock Prices in the UAE Financial Markets. Journal of Transnational Management, 16, 3-19. https://doi.org/10.1080/15475778.2011.549441

Angela-Maria, F., Maria, P. A., \& Miruna, P. M. (2015). An Empirical Investigation of Herding Behavior in CEE Stock Markets under the Global Financial Crisis. Procedia Economics and Finance, 25, 354-361. https://doi.org/10.1016/S2212-5671(15)00745-5

Antoniou, C., Galariotis, E. C., \& Read, D. (2014). Ambiguity Aversion, Company Size and the Pricing of Earnings Forecasts. European Financial Management, 20, 633-651. https://doi.org/10.1111/j.1468-036X.2012.00651.x

Atiq, M., Rafiq, M., \& Roohullah. (2010). Factors Affecting Stock Prices: A Case Study of Karachi Stock Exchange (KSE). B\&ER, 2, 7-12.

http://www.imsciences.edu.pk/files/journals/Vol.\%202\%20No.\%201.\%20April\%202010/JB\&ER 
-2.pdf

Aurangzeb (2012). Factors Affecting Performance of Stock Market: Evidence from South Asian Countries. International Journal of Academic Research in Business and Social Sciences, 2, 1-15. http://www.hrmars.com/admin/pics/1086.pdf

Baimbridge, M. (2016). The Labour Case for Brexit: Economic Costs of Membership. http://www.tuaeu.co.uk/wp-content/uploads/2016/06/The-Labour-Case-for-Brexit.pdf

Baker, H. K., Hargrove, M. B., \& Haslem, J. A. (1977). An Empirical Analysis of the Risk Return Preferences of Individual Investors. Journal of Financial and Quantitative Analysis, 12, 377389. https://doi.org/10.2307/2330541

Baker, M., \& Wurgler, J. (2006). Investor Sentiment and the Cross-Section of Stock Returns. Journal of Finance, 61, 1645-1680. https://doi.org/10.1111/j.1540-6261.2006.00885.x

Barber, B. M., \& Odean, T. (1999). The Courage of Misguided Convictions. Financial Analysts Journal, 55, 41-55. https://doi.org/10.2469/faj.v55.n6.2313

Barber, B. M., \& Odean, T. (2000). Trading Is Hazardous to Your Wealth: The Common Stock Investment Performance of Individual Investors. The Journal of Finance, 55, 773-806.

https://doi.org/10.1111/0022-1082.00226

Barber, B. M., \& Odean, T. (2011). The Behavior of Individual Investors. http://ssrn.com/abstract $=1872211$

Beaulieu, M. C., Cosset, J. C., \& Essaddam, N. (2006). Political Uncertainty and Stock Market Returns: Evidence from the 1995 Quebec Referendum. Canadian Journal of Economic, 39, 621-642. https://doi.org/10.1111/j.0008-4085.2006.00363.x

Benartzi, S. (2001). Excessive Extrapolation and the Allocation of 401(k) Accounts to Company Stock. Journal of Finance, 56, 1747-1764. https://doi.org/10.1111/0022-1082.00388

Benartzi, S., \& Thaler, R. (1995). Myopic Loss-Aversion and the Equity Premium Puzzle. Quarterly Journal of Economics, 110, 73-92. https://doi.org/10.2307/2118511

Bennet, E., Amoako, L. O., Charles, R. O., Edward, A., \& Darkwah, J. A. (2012). The Impact of Investors' Sentiment on the Equity Market: Evidence from Ghanaian Stock Market. International Journal of Business Administration, 3, 99-109. https://doi.org/10.5430/ijba.v3n5p99

Blasco, N., Corredor, P., \& Ferreruela, S. (2012). Does Herding Affect Volatility? Implications for the Spanish Stock Market. Quantitative Finance, 12, 311-327.

https://doi.org/10.1080/14697688.2010.516766

Brennan, K. (2013). A Stakeholder Analysis of the BP Oil Spill and the Compensation Mechanisms Used to Minimize Damage.

http://www.usf.edu/business/documents/undergraduate/honors/thesis-brennan-katelyn.pdf

Bu, X., \& Tian, R. G. (2012). Quality Award and Market Performance: An Empirical Investigation about Chinese Stock Market. Journal of Applied Business and Economics, 13, 25-35. http://www.na-businesspress.com/JABE/BuX Web13 3 .pdf

Byrne, B. A., \& Utkus, W. S. P. (2013). Understanding How the Mind Can Help or Hinder Investment Success. VAM-2013-05-08-0790.

https://www.vanguard.co.uk/documents/portal/literature/behavourial-finance-guide.pdf

Chan, K., Covrig, V., \& Lilian, N. G. (2005). What Determines the Domestic Bias and Foreign Bias? Evidence from Mutual Fund Equity Allocations Worldwide. Journal of Finance, LX, 1495-1534. https://doi.org/10.1111/j.1540-6261.2005.768 1.x

Chang, C. C., Yu, S., Reinstein, A., \& Churyk, N. T. (2004). An Overview of Investor Sentiment in Stock Market.

http://www.wiu.edu/cbt/jcbi/documents/NAASFeb2016/SpecialNAASIssueFeb2016-InvestorSe 
ntiment.pdf

Chang, E. C., Cheng, J. W., \& Khorana, A. (2000). An Examination of Herd Behavior in Equity Markets: An International Perspective. Journal of Banking and Finance, 24, 1651-1679. https://doi.org/10.1016/S0378-4266(99)00096-5

Chang, H.-L., Chen, Y.-S., Su, C.-W., \& Ya-Wen, C. (2008). The Relationship between Stock Price and EPS: Evidence Based on Taiwan Panel Data. Economics Bulletin, 3, 1-12. http://www.accessecon.com/pubs/EB/2008/Volume3/EB-08C30034A.pdf

Chen, A. H., \& Siems, T. F. (2004). The Effects of Terrorism on Global Capital Markets. The European Journal of Political Economy, 20, 349-366. https://doi.org/10.1016/j.ejpoleco.2003.12.005

Chew, S. H., Ebstein, R. P., \& Zhong, S. (2012). Ambiguity Aversion and Familiarity Bias: Evidence from Behavioral and Gene Association Studies. Journal of Risk and Uncertainty, 44, 1-18. https://doi.org/10.1007/s11166-011-9134-0

Chow, C. C., \& Sarin, R. K. (2001). Comparative Ignorance and the Ellsberg Paradox. Journal of Risk and Uncertainty, 22, 129-139. https://doi.org/10.1023/A:1011157509006

Collins, J. (1957). How to Study the Behavior of Bank Stocks. The Analysts Journal, 13, 109-113. https://doi.org/10.2469/faj.v13.n2.109

Copeland, T. E., \& Weston, J. F. A. (2005). Financial Theory and Corporate Policy (4th ed.). Boston, Mass : Pearson Addison-Wesley, Cop.

COSO (2010). Financial Fraud at U.S. Public Companies often Results in Bankruptcy or Failure, with Significant Immediate Losses for Shareholders and Penalties for. http://coso.org/documents/COSOReleaseonFraudulentReporting2010PDF 001.pdf

Crumbaker, B. R. (2016). Brexit Offers a Golden Lesson for Investors. http://www.washingtontimes.com/news/2016/jun/29/brexit-offers-a-golden-lesson-for-investors/

Dhingra, S., Huang, H., Ottaviano, G., Pessoa, J. P., Sampson, T., \& Reenen, J. Van. (2016). The Costs and Benefits of Leaving the EU: Trade Effects.

http://cep.lse.ac.uk/pubs/download/brexit08 book.pdf

Dimmock, S. G., Kouwenberg, R., Mitchell, O. S., \& Peijnenburg, K. (2013). Ambiguity Aversion and Household Porfolio Choice: Empirical Evidence. NBER Working Paper No. 18743. http://www.nber.org/papers/w18743.pdf

Ding, H., Molchanov, A. E., \& Stork, P. A. (2011). The Value of Celebrity Endorsements: A Stock Market Perspective. Marketing Letters, 22, 147-163. https://doi.org/10.1007/s11002-010-9117-y

Doukas, J. A. (2013). Media Endorsements and Stock Returns: Evidence from Announcement of New Products. http://etheses.dur.ac.uk/8458/

Dullien, S., Kotte, D. J., Márquez, A., \& Priewe, J. (2010). The Financial and Economic Crisis of 2008-2009 and Developing Countries. UNCTAD/GDS/MDP/2010/1, United Nations Publication. http://unctad.org/en/Docs/gdsmdp20101 en.pdf

Ehrhardt, M. C., \& Brigham, E. F. (2014). Corporate Finance: A Focused Approach (5th ed.). USA: South-Western Cengage Learning.

Eichengreen, B., \& Mody, A. (1998). What Explains Changing Spreads on Emerging Market Debt: Fundamentals or Market Sentiment? NBER Working Paper No. 6408.

http://www.nber.org/papers/w6408.pdf

Elan, L. S. (2010). Behavioral Patterns and Pitfalls of U. S. Investors. Federal Research Division, Library of Congress. https://www.sec.gov/investor/locinvestorbehaviorreport.pdf

Ellsberg, D. (1961). Risk, Ambiguity, and the Savage Axioms. Quarterly Journal of Economics, 75, 643-669. https://doi.org/10.2307/1884324 
Fama, E., Fisher, L., Jensen, M., \& Roll, R. (1969). The Adjustment of Stock Prices to New Information. International Economic Review, 10, 1-21. https://doi.org/10.2307/2525569

Farayibi, A. O. (2015). The Impact of Risk on Investment Decision in Nigeria. Research Journal of Finance and Accounting, 6, 52-59.

http://www.iiste.org/Journals/index.php/RJFA/article/viewFile/27833/28536

Fischhoff, B., Slovic, P., Lichtenstein, S., Read, S., \& Combs, B. (1978). How Safe Is Safe Enough? A Psychometric Study of Attitudes towards Technological Risks and Benefits. Policy Sciences, 9, 127-152. https://doi.org/10.1007/BF00143739

Foad, H. (2010). Familiarity Bias. https://doi.org/10.1002/9781118258415.ch15

Fox, C. R., \& Tversky, A. (1995b). Ambiguity Aversion and Comparative Ignorance. The Quarterly Journal of Economics, 110, 585-603. https://doi.org/10.2307/2946693

Full Fact Team (2016). The UK's EU Membership Fee. https://fullfact.org/europe/our-eu-membership-fee-55-million/

Ganzach, Y. (2000). Judging Risk and Return of Financial Assets. Organizational Behavior and Human Decision Processes, 83, 353-370. https://doi.org/10.1006/obhd.2000.2914

Glushkov, D. (2006). Sentiment Beta. https://doi.org/10.2139/ssrn.862444

Haritha, P., \& Uchil, R. (2016). Conceptual Framework on Market Factors Affecting Investor's Sentiments and the Effect of Behavioral Pitfalls on Investment Decision Making. IOSR Journal of Economics and Finance, 29-34. http://www.iosrjournals.org/iosr-jef/papers/SIFICO/Version-1/5. 29-34.pdf

Harris, M., \& Raviv, A. (1993). Differences of Opinion Make a Horse Race. Review of Financial Studies, 6, 473-506. https://doi.org/10.1093/rfs/5.3.473

Hartono, J. (2004). The Recency Effect of Accounting Information. GadjahMada International Journal of Business, 6, 85-116. http://jurnal.ugm.ac.id/gamaijb/article/view/5536

Hendricks, K. B., \& Singhal, V. R. (2008). The Effect of Supply Chain Disruptions on Shareholder Value. Total Quality Management \& Business Excellence, 19, 777-791. https://doi.org/10.1080/14783360802159444

Hickson, K., \& Miles, J. (2016). The Labour Case for Brexit. http://www.tuaeu.co.uk/wp-content/uploads/2016/06/The-Labour-Case-for-Brexit.pdf

Hirshliefer, D. (2001). Investor Psychology and Asset Pricing. Journal of Finance, 56, 1533-1598. https://doi.org/10.1111/0022-1082.00379

Huberman, G. (2001). Familiarity Breeds Investment. Review of Financial Studies, 14, 659-680. https://doi.org/10.1093/rfs/14.3.659

Huiwen, Z., \& Sun, L. (2012). The Influence of Investor Sentiment on Stock Return and Its Volatility under Different Market States (pp. 337-341). Fifth International Conference of Business Intelligence and Financial Engineering (BIFE), Lanzhou, 18-21 August 2012.

Hung, A., Heinberg, A., \& Yoong, J. (2010). Do Risk Disclosures Affect Investment Choice? RAND Labor and Population Working Paper No. WR-788.

https://www.rand.org/content/dam/rand/pubs/working_papers/2010/RAND WR788.pdf

Ibrahim, M., \& Aziz, M. (2003). Macroeconomic Variables and the Malaysian Equity Market: A Rolling through Subsamples. Journal of Economic Studies, 30, 6-27. https://doi.org/10.1108/01443580310455241

Ishfaq, M., \& Anjum, N. (2015). Effect of Anchoring Bias on Risky Investment Decision. Evidence from Pakistan Equity Market. Journal of Poverty, Investment and Development, 14, 1-9. http://www.iiste.org/Journals/index.php/JPID/article/view/24508/25083

Jagongo, A., \& Mutswenje, V. S. (2014). A Survey of the Factors Influencing Investment Deci- 
sions: The Case of Individual Investors at the NSE. International Journal of Humanities and Social Science, 4, 92-102.

http://www.ijhssnet.com/journals/Vol 4 No 4 Special Issue February 2014/11.pdf

Johnson, M., Agnew, H., \& Childs, M. (2016). Hedge Funds Win Big from Brexit Bets. https://next.ft.com/content/c02fe256-3aaf-11e6-8716-a4a71e8140b0\#axzz4CaN72vu0

Johnston, R. B., \& Nedelescu, O. M. (2005). The Impact of Terrorism on Financial Markets. IMF Working Paper No. WP/05/60.

http://www.imf.org/external/pubs/ft/wp/2005/wp0560.pdf

Jones, E., \& Danbolt, J. (2005). Empirical Evidence on the Determinants of the Stock Market Reaction to Product and Market Diversification Announcements. Applied Financial Economics, 18, 617-627. https://doi.org/10.1080/09603100500065461

Kahneman, D., \& Tversky, A. (1979). Prospect Theory: An Analysis of Decision under Risk. Econometrica, 47, 263-292. https://doi.org/10.2307/1914185

Keller, L. R., Sarin, R. K., \& Sounderpandian, J. (2007). An Examination of Ambiguity Aversion: Are Two Heads Better Than One? Judgment and Decision Making, 2, 390-397. http://journal.sjdm.org/jdm7619.pdf

Khan, K. I., Aamir, M., Qayyum, A., Nasir, A., \& Khan, M. I. (2011). Can Dividend Decisions Affect the Stock Prices: A Case of Dividend Paying Companies of KSE. International Research Journal of Finance and Economics, 76, 67-74. http://www.internationalresearchjournaloffinanceandeconomics.com/ISSUES/IRJFE Issue 76. $\underline{\mathrm{htm}}$

Khan, S. H. (2009). Determinants of Share Price Movements in Bangladesh: Dividends and Retained Earnings. Karlskrona: Blekinge Institute of Technology. http://www.diva-portal.org/smash/get/diva2:832110/FULLTEXT01.pdf

Kottasova, I., \& Petroff, A. (2016). This Is Brexit: London and European Stocks Get Crushed. http://money.cnn.com/2016/06/24/investing/brexit-london-stocks-crashing/

Krishnan, K. M., \& Satish, R. (2016). Investors Sentiments to Mergers Announement \& Stock Market Reaction. International Journal of Applied Engineering Research, 11, 1266-1272. http://www.ripublication.com/ijaer16/ijaerv11n2 93.pdf

Kurihara, Y. (2006). The Relationship between Exchange Rate and Stock Prices during the Quantitative Easing Policy in Japan. International Journal of Business, 11, 375-386. http://www.craig.csufresno.edu/ijb/Volumes/Volume\%2011/V114-3.pdf

Lash, H., \& Krudy, E. (2016). World Stocks Tumble as Britain Votes for EU Exit. http://www.reuters.com/article/us-global-markets-idUSKCN0Z92MZ

Lee, C. M. C., Shleifer, A., \& Thaler, R. H. (1991). Investor Sentiment and the Closed-End Fund Puzzle. The Journal of Finance, 46, 75-109. https://doi.org/10.1111/j.1540-6261.1991.tb03746.x

Lee, R. P., Chen, Q., \& Hartmann, N. N. (2015). Enhancing Stock Market Return with New Product Preannouncements: The Role of Information Quality and Innovativeness. Journal of Product Innovation Management, 33, 455-471.

Liang, C. (2013). The Impact of Merger and Acquisition Announcements on Firms' Stock Performance: Evidence from Hong Kong Stock Market. http://library2.smu.ca/xmlui/handle/01/24964

Ling, D. C., Naranjo, A., \& Scheick, B. (2014). Investor Sentiment, Limits to Arbitrage and Private Market Returns. Real Estate Economics, 42, 531-577. https://doi.org/10.1111/1540-6229.12037

Liu, M. H., \& Shrestha, K. M. (2008). Analysis of the Long-Term Relationship between Macroeconomic Variables and the Chinese Stock Market Using Heteroskedasticity Cointegration. 
Managerial Finance, 34, 744-755. https://doi.org/10.1108/03074350810900479

Lokko, V. K. (2016). Cedi Falls against Pound as UK Exits EU. http://citifmonline.com/2016/06/24/cedi-falls-against-pound-as-uk-votes-to-exit-eu/

Lott, J., \& Karpoff, J. M. (1998). Punitive Damages: Their Determinants, Effects on Firm Value, and the Impact of Supreme Court and Congressional Attempts to Limit Awards (No. 58). http://chicagounbound.uchicago.edu/cgi/viewcontent.cgi?article=1399\&context=law and eco $\underline{\text { nomics }}$

Luo, N. (2012). The Impact of Natural Disasters on Global Stock Market: the Case of the Japanese 2011 Earthquake. Halifax: Saint Mary's University. http://library2.smu.ca/xmlui/bitstream/handle/01/24714/luo nannan mrp 2012.pdf;sequence $=1$

Mackenzie, M., \& Platt, E. (2016). How Global Markets Are Reacting to UK's Brexit Vote. http://www.ft.com/cms/s/2/50436fde-39bb-11e6-9a05-82a9b15a8ee7.html\#axzz4CXgCQomh

Maierhofer, S. (2011). 5 Worst Disasters-How Did the Stock Market React? http://www.nasdaq.com/article/5-worst-disasters-how-did-the-stock-market-react-cm68124

Malkiel, B. (2003). The Efficient Market Hypothesis and Its Critics. The Journal of Economic Perspectives, 17, 59-82. https://doi.org/10.1257/089533003321164958

Maranjian, S. (2013). What Is Risk and Return? http://www.aol.com/article/2013/04/24/what-is-risk-and-return/20546858/

Maria, S. D. S. (2013). Improving Influence Operations by Defining Influence and Influence Operations. http://www.dtic.mil/get-tr-doc/pdf?AD=ADA606282

Markowitz, H. (1952). Portfolio Section. Journal of Finance, 7, 77-91. https://www.math.ust.hk/ maykwok/courses/ma362/07F/markowitz JF.pdf

Martin, D., \& Joomis, K. (2007). Building Teachers: A Constructivist Approach to Introducing Education. Belmont, CA: Wadsworth Cangage Learning. http://www.cengage.com/resource uploads/downloads/0495570540 162121.pdf

Matheson, T. (2011). Taxing Financial Transactions: Issues and Evidence. IMF Working Paper No. WP/11/54. https://doi.org/10.5089/9781455220984.001

McKibbin, W., \& Stoeckel, A. (2009). The Global Financial Crisis: Causes and Consequences. Working Paper of International Economics No. 2.09.

http://www.lowyinstitute.org/files/pubfiles/McKibbin and Stoeckel, The global financial cri sis.pdf

Merikas, A., Merikas, A., Vozikis, G. S., \& Prasad, D. (2011). Economic Factors and Individual Investor Behavior: The Case of the Greek Stock Exchange. Journal of Applied Business Research, 20, 93-98. https://doi.org/10.19030/jabr.v20i4.2227

Miles, J. (2016). The Labour Case for Brexit: Managing Immigration. http://www.tuaeu.co.uk/wp-content/uploads/2016/06/The-Labour-Case-for-Brexit.pdf

Mitchell, O., \& Utkus, S. (2002). Company Stock and Retirement Plan Diversification. Pension Research Council Working Paper No. 2002-4. https://doi.org/10.2139/ssrn.304461

Morris, N. (2013). Former Chancellor Nigel Lawson Calls for UK to Leave European Union. http://campbellmgold.com/archive blowing in the wind/lawson uk to leave eu may 2013. pdf

Muelbroek, L. (2002). Company Stock in Pension Plans: How Costly Is It? Harvard Business School Working Paper No. 02-058.

http://www.hbs.edu/faculty/Publication\%20Files/02-058 7e51c79e-3ad6-4b75-96bf-d7d7336e1 ce9.pdf 
Mullen, J., Kottasova, I., \& Gillespie, P. (2016). Dow Plunges over 600 Points as U.K. "Earthquake" Crushes Global Markets. http://money.cnn.com/2016/06/23/investing/eu-referendum-markets/index.html?iid=EL

Neal, R., \& Wheatley, S. M. (1998). Do measures of Investor Sentiment Predict Returns? Journal of Financial and Quantitative Analysis, 33, 523-547. http://www.jstor.org/stable/2331130

Neuhierl, A., Scherbina, A., \& Schlusche, B. (2013). Market Reaction to Corporate Press Releases. Journal of Financial \& Quantitative Analysis, 48, 1207-1240. https://doi.org/10.1017/S002210901300046X

Njanike, K., Katsuro, P., \& Mudzura, M. (2009). Factors Influencing the Zimbabwe Stock Exchange Performance (2002-2007). Annals of the University of Petroşani, Economics, 9, 161172. http://upet.ro/annals/economics/pdf/2009/20090221.pdf

Norgren, C. (2010). The Causes of the Global Financial Crisis and Their Implications for Supreme Audit Institutions.

http://www.intosai.org/uploads/gaohq4709242v1finalsubgrouplpaper.pdf

Odean, T. (1998). Volume, Volatility, Price and Profit When All Traders Are Above Average. Journal of Finance, 53, 1887-1934. https://doi.org/10.1111/0022-1082.00078

Peirson, G., Brown, R., Easton, S., Howard, P., \& Pinder, S. (2009). Business Finance (10th ed.). Australia: McGraw-Hill.

Raiffa, H. (1961). Risk, Ambiguity, and the Savage Axioms: Comment. Quarterly Journal of Economics, 75, 690-694. https://doi.org/10.2307/1884326

Reenen, J. Van. (2016). BREXIT 2016: Policy Analysis from the Centre for Economic Performance. http://cep.lse.ac.uk/pubs/download/brexit08 book.pdf

Rehman, M. U. (2013). Investor's Sentiments and Stock Market Volatility: An Empirical Evidence from Emerging Stock Market. Pakistan Journal of Commerce and Social Sciences, 7, 80-90. http://jespk.net/publications/108.pdf

Rezagholizadeh, M., Lin, C.-Y. C., Yavari, K., \& Sahabi, B. (2013). The Conditional Relationship between Risk and Return in Iran's Stock Market.

http://www.des.ucdavis.edu/faculty/Lin/Iran risk return paper.pdf

Rigobon, R., \& Sack, B. (2003). Measuring the Reaction of Monetary Policy to the Stock Market. Quarterly Journal of Economics, 118, 639-669. https://doi.org/10.1162/003355303321675473

Riley, C., \& Long, H. (2016a). Biggest Losers: "Brexit” Is Already Hitting These Companies. http://money.cnn.com/2016/06/24/investing/brexit-uk-companies/index.html?iid=hp-topleaddom

Riley, C., \& Long, H. (2016b). Brexit Shock Vote: What You Need to Know. http://money.cnn.com/2016/06/24/news/economy/brexit-uk-european-union-vote/index.html ?iid=EL

Rudd, K. (2009). The Global Financial Crisis. http://themonthly.com.au/monthly-essays-kevin-rudd-global-financial-crisis-1421

Russell, K., \& Lee, C. J. (2016). Fallout from Britain's Exit: Markets, Immigration and Trade. http://www.nytimes.com/interactive/2016/06/23/international-home/brexit-leave-repercussion s.html

Sarin, R. K., \& Weber, M. (1993). Effects of Ambiguity in Market Experiments. Management Science, 39, 602-615. https://doi.org/10.1287/mnsc.39.5.602

Schweitzer, R. (1989). How Do Stock Returns React to Special Events? http://www.phil.frb.org/research-and-data/publications/business-review/1989/brja89rs.pdf

Securities and Exchange Commission (2014). How Fees and Expenses Affect Your Investment 
Portfolio, SEC Investor Bulletin. http://www.concordadvisory.com/node/192

Seiler, M. J., Seiler, V. L., Traub, S., \& Harrison, D. M. (2007). Familiarity Bias and the Status Quo Alternative.

http://citeseerx.ist.psu.edu/viewdoc/download?doi=10.1.1.320.9840\&rep=rep1\&type=pdf

Seyhun, N. (1998). Investment Intelligence from Insider Trading. Cambridge: MIT Press. https://mitpress.mit.edu/books/investment-intelligence-insider-trading

Shalom-gilo, R. (2013). Effects of Level of Investors' Confidence and Herding Behavior on Stock Prices and Their Volatilities.

http://coller.tau.ac.il/sites/nihul.tau.ac.il/files/media server/Recanati/management/seminars/ac count/Effects.pdf

Shapira, Y., Berman, Y., \& Ben-Jacob, E. (2014). Modelling the Short Term Herding Behaviour of Stock Markets. New Journal of Physics, 16, 1-16.

https://doi.org/10.1088/1367-2630/16/5/053040

Sharif, T., Purohit, H., \& Pillai, R. (2015). Analysis of Factors Affecting Share Prices: The Case of Bahrain Stock Exchange. International Journal of Economics and Finance, 7, 207-216. https://doi.org/10.5539/ijef.v7n3p207

Sheldon, E. (2016). 4 Vital Investing Lessons from the Brexit Result. from https://uk.finance.yahoo.com/news/4-vital-investing-lessons-brexit-101442884.html

Shrestha, P. K., \& Biggyan, R. S. (2014). Determinants of Stock Market Performance in Nepal (No. NRB-WP-24). http://www.nrb.org.np/ecorev/pdffiles/vol26-2 art2.pdf

Smales, L. A. (2013). Impact of Macroeconomic Announcements on Interest Rate Futures: HighFrequency Evidence from Australia. Journal of Financial Research, 36, 371-388. https://doi.org/10.1111/j.1475-6803.2013.12015.x

Somoye, R., Akintoye, I., \& Oseni, J. (2009). Determinants of Equity Prices in the Stock Markets. International Research Journal of Finance and Economics, 30, 177-189. http://connection.ebscohost.com/c/articles/43972866/determinants-equity-prices-stock-markets

Strong, N., \& Xu, X. (2003). Understanding the Equity Home Bias: Evidence from Survey Data. Review of Economics and Statistics, 85, 307-312. https://doi.org/10.1162/003465303765299837

Subaih, O. (2013). The Effect of Stock Split Announcements on Stock Prices: an Empirical Investigation for the Toronto Stock Exchange (TSX).

http://library2.smu.ca/bitstream/handle/01/24835/subaih omer mrp 2013.pdf? sequence $=1$

Swedroe, L. (2013). The Impact of News Events on Market Prices. http://www.cbsnews.com/news/the-impact-of-news-events-on-market-prices/

Tanner, L. (2015). Understand Your Familiarity Bias to Be a Better Investor. https://www.nerdwallet.com/blog/investing/understand-familiarity-bias-investor/

The Guardian (2016). Brexit Panic Wipes \$2 Trillion off World Markets-As It Happened. https://www.theguardian.com/business/live/2016/jun/24/global-markets-ftse-pound-uk-leaveeu-brexit-live-updates

Thorp, W. A. (2004). Investor Sentiment as a Contrarian Indicator. http://www.aaii.com/journal/sentimentsurveyarticle

Trautmann, S. T., Vieider, F. M., \& Wakker, P. P. (2008). Causes of Ambiguity Aversion: Known versus Unknown Preferences. Journal of Risk and Uncertainty, 36, 225-243.

https://doi.org/10.1007/s11166-008-9038-9

Tse, A. (2010). BP Oil Spill Driving BP Stock Down. https://www.thestreet.com/story/10742947/1/bp-oil-spill-driving-bp-stock-down.html

Varian, H. R. (1989). Differences of Opinion in Financial Markets. In C. S. Courtenay (Ed.), Fi- 
nancial Risk: Theory, Evidence and Implications (pp. 3-37). Eleventh Annual Economic Policy Conference of the Federal Reserve Bank of St. Louis, Boston, MA. Boston, MA: Kluwer Academic.

Vega, C. (2006). Stock Price Reaction to Public and Private Information. Journal of Financial Economics, 82, 103-133. https://doi.org/10.1016/j.jfineco.2005.07.011

Verma, N. (2016). Impact of Behavioral Biases in Investment Decision and Strategies. Journal of Management Research and Analysis, 3, 28-30. https://doi.org/10.5958/2394-2770.2016.00004.1

Vincent, O., \& Bamiro, K. (2013). Fluctuations in Stock Market Prices: What Went Wrong, Its Implications to Nigerian Economy? International Journal of Computer Applications, 63, 1320. http://research.ijcaonline.org/volume63/number19/pxc3885612.pdf

Wadsworth, J., Dhingra, S., Ottaviano, G., \& Reenen, J. Van. (2016). Brexit and the Impact of Immigration on the UK. http://cep.lse.ac.uk/pubs/download/brexit08 book.pdf

Walker, T. J., Pukthuanthong, K., \& Barabanov, S. S. (2006). On the Stock Market's Reaction to Major Railroad Accidents. Journal of the Transportation Research Forum, 45, 23-39. http://journals.oregondigital.org/index.php/trforum/article/view/871/766

Wang, Y. M., Li, C. A., \& Lin, C. F. (2009). The Impact of Investor Sentiment on the Futures Market: Evidence from the Taiwan Futures Exchange. International Research Journal of Finance and Economics, 29, 134-151. http://citeseerx.ist.psu.edu/viewdoc/download?doi=10.1.1.322.7639\&rep=rep1\&type=pdf

Wasik, J. F. (2013). The Erosive Effect of Expenses on a Portfolio's Value. http://www.nytimes.com/2013/10/16/your-money/the-erosive-effect-of-expenses-on-a-portfoli os-value.html? $\mathrm{r}=0$

Webber, D. (2016). The Road to Brexit and What It Would Mean. http://knowledge.insead.edu/node/4546/pdf

Woolridge, J. R., \& Snow, C. C. (1990). Stock Market Reaction to Strategic Investment Decisions. Strategic Management Journal, 11, 353-363. https://doi.org/10.1002/smj.4250110503

Wu, S. J., \& Lee, W. M. (2015). Predicting Severe Simultaneous Bear Stock Markets Using Macroeconomic Variables as Leading Indicators. Finance Research Letters, 13, 196-204.

https://doi.org/10.1016/j.frl.2015.01.003

Yan, S. (2016). Global Banks Hammered by U.K. Vote. http://money.cnn.com/2016/06/24/investing/brexit-bank-impact/index.html

Zacks, L. (1979). EPS Forecasts: Accuracy Is Not Enough. Financial Analysts Journal, 35, 53-55. https://doi.org/10.2469/faj.v35.n2.53

Zaharyeva, I. (2009). Herding toward the Market: Evidence from the Stock Market of Ukraine. Kyiv School of Economics. http://www.kse.org.ua/uploads/file/ZAHAREVA.pdf

Zheng, Y. (2015). The Linkage between Aggregate Investor Sentiment and Metal Futures Returns: A Nonlinear Approach. The Quarterly Review of Economics and Finance, 58, 128-142. https://doi.org/10.1016/j.qref.2015.02.008 
Submit or recommend next manuscript to SCIRP and we will provide best service for you:

Accepting pre-submission inquiries through Email, Facebook, LinkedIn, Twitter, etc.

A wide selection of journals (inclusive of 9 subjects, more than 200 journals)

Providing 24-hour high-quality service

User-friendly online submission system

Fair and swift peer-review system

Efficient typesetting and proofreading procedure

Display of the result of downloads and visits, as well as the number of cited articles

Maximum dissemination of your research work

Submit your manuscript at: http://papersubmission.scirp.org/

Or contact jfrm@scirp.org 